\title{
Modelling the Behaviour of Government Spending and Economic Growth in Six ECOWAS Countries (1981-2013)
}

\author{
Matthew Abiodun Dada \\ Department of Economics and Business Studies, College of Social and Management Sciences Wellspring University, Benin City, Nigeria
}

Email address:

mattabeyvoice2@yahoo.com

\section{To cite this article:}

Matthew Abiodun Dada. Modelling the Behaviour of Government Spending and Economic Growth in Six ECOWAS Countries (1981-2013). International Journal of Economics, Finance and Management Sciences. Vol. 5, No. 1, 2017, pp. 34-56. doi: 10.11648/j.ijefm.20170501.14

Received: August 12, 2016; Accepted: August 22, 2016; Published: January 4, 2017

\begin{abstract}
This study examined the behaviour of government spending and economic growth in six ECOWAS countries using ARDL and UVAR-based modified granger non-causality approach. Secondary data covering1981-2013 were sourced on key variables from (WDIs) 2014 edition. The result of Johansen and ARDL bound test suggests a long run equilibrium relationship between government spending and economic growth in all the six countries. The result of the modified ARDL indicates that variables adjust to a long run equilibrium path after a short run deviation. The ECM coefficient is negatively signed and significant at 5 and even at 1 percent in line with a priori expectation. This provides strong support for the long run equilibrium relationship. However, the speed of adjustment to long run equilibrium path varies across the six countries. The causality test result suggests that bidirectional causality exists for Gambia, Cote d'Ivoire, Senegal and Burkina Faso while unidirectional causality running from economic growth to government spending was found for Nigeria and Ghana. There is no support for the feedback hypothesis. Policy makers in this region are enjoined to caution on the call for fiscal consolidation but rather consider the fiscal space alternative to advance the developing economies in this sub-region. The study therefore concluded that there is a cause-effect relationship between government spending among other variables and economic growth in the developing ECOWAS countries.
\end{abstract}

Keywords: Government Spending, Economic Growth, ARDL Bound Test,

Toda and Yamamoto Modified Granger Non-causality, Error Correction Models, ECOWAS Countries

\section{Introduction}

The enquiry on the relationship between government spending and economic growth has ever remained a subject of interest among scholars and economic writers since the inception of Keynes and the Keynesian economics. The debate on whether large government is good or bad for economic growth has generated mixed reactions across the globe. There has been a growing concern that large government has adverse effect on the long run growth of the economy. This pessimistic view also remains to characterize the long run equilibrium relation and causality between government spending and economic growth. The submission of this school of thought is that there is non-existence of long run equilibrium relation between government spending and economic growth. They share the view that causality runs from economic growth to government spending indicating that government spending is an endogenous factor which is determined by economic growth. For this reason, government spending is seen as a result and not the cause of economic growth. The policy recommendation in this case usually suggests a downsizing of government activity and budgets in order to check the excessive growth of government spending. The main idea is to ensure that government spending does not out-grow the overall output of the economy. This has been the reason why a wide-range of fiscal consolidation programmes have been put in place to reduce government spending most especially in countries facing fiscal imbalances and high debt burdens (IMF, 2003).

Contrary to this view is the call for 'fiscal space' in which government spending is expected to be jerked up to allow for the provision of public goods that foster economic growth, (Heller, 2005). This school of thought holds an optimistic view on the relationship between government spending and economic growth. The submission of this school of thought is that there exists a long run equilibrium relation between 
government spending and economic growth. They are also of the view that causality runs from government spending to economic growth indicating that government spending is an exogenous factor which determines economic growth. For this reason, government spending is seen as a cause and not the result of economic growth.

These opposing policy recommendations are based on conflicting views on the relationship between government spending and economic growth, while a lot of arguments in favour of large government as an accelerator of economic growth exist in the literature, there are also several arguments against large government. For instance, empirical evidence in favour of large government is provided in some economies and regions where supports are found for long run equilibrium relation and causality between government spending and economic growth. Such studies include; AbuBader and Abu-Quarn (2003a), for Israel and Syria, Haliciogglu (2005), for Turkey, Govindaraju et al. (2010), for Malaysia, Wahab et al.(2011) for Nigeria, Kalam and Aziz (2009), for Bangladesh, Kumar (2009), for China, HongKong, Japan, Taiwan and South Korea, Yaya (2015), for Gabon, Senegal and Burkina Faso, Ebaidalla (2013), for Sudan.

However, the causality direction in some other studies runs from economic growth to government spending especially Olomola (2004) and Akinlo (2013) in their own studies on the Nigerian economy provide evidence in support of long run relationship with causality direction running from economic growth to government spending. Mutuku and Kimani (2012) also found similar result for Sudanese economy, providing support for the growth-spend hypothesis in line with the Wagnerian hypothesis. Ansari (1997) also confirmed Wagner law for the Ghanaian economy while Sevitenyi (2012) found support for unidirectional causality running from government spending to economic growth. There was a support for the feedback hypothesis in some of these countries indicating a bi-directional causality relation while in some, there was no support for the feedback hypothesis indicating a support for unidirectional causality between government spending and economic growth.

Similarly, empirical evidence against large government has also been provided in some economies and regions most especially in the works of Gwartney et al., (1998), Leod (2003), Schaltegger and Torgler (2006), Mitchell (2005), etc. Studies with no support for long run equilibrium relation and causality between government spending and economic growth include; Huang (2006), for China and Taiwan, Magazzino (2010), for EU-countries, Dogan and Tang(2006), for Indonesia, Malaysia, Singapore and Thailand, Abu-Bader and Abu-Quarn (2003b), for Egypt and Chimobi (2009), for Nigeria. Also, Frimpong and Oteng-Abaiye (2009), found neither support for Wagner law nor Keynesian view for three ECOWAS countries in the eco-zone sub-group called WAMZ that is Gambia, Ghana and Nigeria. This may suggest that pruning down or jerking up government spending might not be a necessary policy action to achieve the steady growth in those economies.
One of the major factors raised to buttress the view against large government is that policy intervention generates its own distortions, as it requires raising taxes, or borrowing or resort to the use of seigniorage that is printing of money by the monetary authority. Each of these options has its own adverse effect on the economy. Raising taxes distorts incentives; borrowing may lead to a credit squeeze which subsequently translates into an increase in the rate of interest cumulating into crowding-out effect on private investment. Using the seigniorage option would translate into inflation which also affects private consumption negatively.

Those who argue in favour of large government have also raised a number of factors to buttress their view; one of these factors is that government provides public goods, as well as correct for market failure through income redistribution and stabilization functions. Public goods represent important variable inputs in the production function. It is a common knowledge that an increase in the supply of public goods would, all things being equal, increase the size of government spending since more input is required whenever there is need to expand or produce more output. In this regard, raising the supply of public goods would necessitate an increase in government spending. This is because public goods because of their nature may not be desirable to be produced by the private sector but such goods aid productivity in the private sector who are the drivers of growth. It is strongly assumed that the greater the size of government spending, all things being equal, the higher the supply of public goods. Developing countries are characterized with low per capita income as well as low government spending per capita. The quantity of public goods supplied to the market is determined by the magnitude of government spending in the economy.

The magnitude of government spending varies a great deal across time and regions, it is no doubt this variation would also cause variation in the supply of public goods most especially in the developing countries. It is no gain saying any longer that the economies of most developing countries are still experiencing a serious deficit in the supply of public goods such as road networks, power supply, security and other social infrastructure that are critical to the survival and performance of the private sector in their overall economic activities. The deficiency in the supply of these aforementioned inputs has led to increased cost of doing business in most of these countries and hence has hampered the growth of the private sector. It is quite convincing that developed countries in the world of today have all overcome this challenge. The behaviour of government spending and economic growth in these countries might differ significantly from their counterpart in the developing countries, especially those in the ECOWAS sub-region.

The involvement of government in the supply of more of these essential inputs is still very crucial to economic progress in most of these countries. Government spending can help in various ways in stimulating output especially in developing countries where there is enough flexibility and lack of effective demand. This can generate favourable 
conditions for the market forces to push up production which will equally generate additional employment.

Figure 1 shows the inter-link among production, income and demand in the developing countries. Low level of production leads to low level of income while low level of income leads to lack of effective demand which aggravates the poverty rate in the developing countries. Figure 1 shows the interplay among production, income and demand in developing countries.

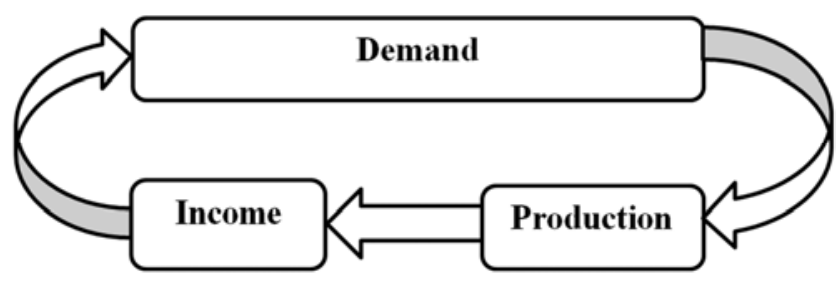

Figure 1. Interlinks among production, income and demand.

The developing countries especially those in the ECOWAS sub-region are characterized with low level of savings and investment, shortage of capital equipment and machinery, etc. Government spending can be chiefly used to create and maintain social overhead. It can be used to create human skills through education and training. This supports the human capital theory which postulates that education and healthcare of workers ensure greater productivity (Olaniyan and Okemakinde, 2008). Government activities aid the process of capital accumulation by helping private investment and production through measures which reduce cost of production or push up the demand or remove particular shortages or bottleneck. Government therefore creates and maintains social overhead which would lead to an all-round reduction in the cost of production and therefore increase the level of efficiency in the market system.

The situation in most of the developing West African countries is not too far from the state of depression, unemployment rate is still very high likewise the level of inequality. The state of insecurity is becoming too alarming; crime rate has been growing at a rate too worrisome likewise the poverty rate (World Bank, 2014). In the situation of this nature, government has a big role to play to move the economy away from the state of moribund. This justifies the call for fiscal space in which government spending is expected to be jerked up to advance the economy. The increasing role of government in the economy as population increases and civilization continues would have an important implication on government finances. The size of government spending is definitely going to be affected as government role in the economy expands. The size of government spending is measured by the amount of GDP purchased either as a consumer or as a producer during a fiscal year. The role of government and its agencies can be determined by the size of government spending.

A lot of factors have been suggested in the literature to have been responsible for the increasing size of government spending. One notable among these is the population growth. Wagner (1890) opined that as population increases, government activities will grow both intensively and extensively leading to an increase in the size of government spending. The population of most developing countries especially those in the ECOWAS sub-region keeps on increasing with little or no control as the poverty rate keeps on rising. The incessant increase in population would continue to put pressure on government finances since the available infrastructure most especially road and electricity become inadequate for the living population. Also, as civilization progresses, government's role continues to expand which implies an increase in the size of government spending. Wagner also proposed that as per capita income increases over time, government spending would also rise which implies that government spending is an increasing function of per capita income. One important question that always comes to mind is "why is it that in a supposedly capitalist economy a huge part of the economy is still subjected to some form of government direction rather than being left to the invisible hand of market forces?. The fact still remains that market mechanism alone cannot perform all economic functions efficiently. A certain level of government participation is needed to guide, correct and augment the market forces to ensure effective and efficient management of the economy.

The conflicting remarks in the literature on the relationship between government spending and economic growth across countries and economies have been left unresolved both theoretically and empirically. For instance, while Wagner and the Wagnerians are of the view that government spending is an endogenous factor determined by economic growth, Keynes and the Keynesians on the contrary hold the view that government spending is an exogenous factor which determines economic growth in any economy. Wagner and the Wagnerians postulate the growth-spend hypothesis while Keynes and the Keynesians postulate the spent-growth hypothesis. The former shares the view of unidirectional causality running from economic growth to government spending while the latter shares the view that unidirectional causality running from government spending to economic growth exists. To address these controversies, different models such as Peacock and Wiseman (1967), Pryor (1969), Gupta (1967), Goffman (1968), Mann (1980), etc. have been used to test the validity of Wagnerian law across economies and regions.

It is quite convincing that many controversial results characterized the existing studies in relation to modeling of long run equilibrium relation and direction of causality between government spending and economic growth. The reasons for these might be in the area of measurement of variables, especially error associated with measurement of government spending, inappropriate econometric application and exclusion of some vital exogenous variables that may serve as additional sources of long run equilibrium relation and causality. Also, another missing link in most studies is the efficiency variable. It is observed that most of these studies have not given attention to efficiency variable. Its inclusion might serve as another source of long run relation 
and causality between government spending and economic growth in the countries of Economic Community of West African States (ECOWAS).

While many studies have been conducted to address these deficiencies in most developed countries and some other regions, such studies are sparse, particularly in the developing economies within the ECOWAS sub-region.

\subsection{Some Stylized Facts About the Economies of the Selected ECOWAS Countries}

The ECOWAS came into being immediately after the signing of the Treaty of Lagos on 28 May, 1975. It is a regional economic group set up to facilitate the growth and development of the member nations. The group was made up of fifteen countries at inception but presently, they consist of sixteen West African countries. Eight of the ECOWAS members formed another organization called eco-zone subgroup popularly known as West African Monetary Union (WAMU). This came into being on $10^{\text {th }}$ of January 1994 after the signing of the Dakar Treaty by the heads of state and government of the eight member countries. The countries involved include Republic of Benin, Burkina Faso, Cote d'Ivoire, Togo, Mali, Niger, Senegal and Guinea-Bissau who later joined on May $2^{\text {nd }}, 1997$. These countries are all Francophone West Africas.

Within the ECOWAS is another eco-zone sub-group called the West African Monetary Zone (WAMZ) formed in the year 2000 by a group of six Anglophone countries. These countries also include Nigeria, Ghana, Sierra-Leone, Guinea, Gambia and Liberia. This group has an agenda of introducing a common currency regime to be called ECO as we have EURO in the European world. Three countries from each of the two eco-zones were involved in this study.

The information presented in Table 1 revealed some stylized facts about the economies of the selected ECOWAS countries considered in this study. The variables of interest are average inflation rate, money sector size, unemployment rate, degree of trade openness, domestic investment per capita, population growth rate, government spending per capita, efficiency of government spending and per capita GDP.

From the table, Cote-d'Ivoire with an average per capita government spending of about (USD103) has an average per capita income estimate of about (USD923) which is the highest in the list of countries considered. However, Senegal with the highest average per capita government spending of about (USD108) has an average per capita income estimate of about (USD694). Ranking these countries all together on the basis of per capita income, Cote-d'Ivoire ranked first, Nigeria second, Senegal third, Ghana fourth, Gambia fifth and Burkina-Faso sixth. However on the basis of government spending per capita, Senegal ranked first, Cote-d'Ivoire second, Ghana third, Nigeria fourth, Burkina-Faso fifth and Gambia sixth. On the basis of output worth of per unit of dollar spent which is the efficiency variable in this study, Nigeria ranked first with (11.8), Cote-d'Ivoire second with (9.9), Ghana third with (9.4), Gambia fourth with (8.6), Senegal fifth with (6.6) and Burkina-Faso sixth with (5.2).

On the basis of domestic investment per capita, Senegal ranked first with (USD135), Ghana second with (USD131), Cote-d'Ivoire third with (USD121), Nigeria fourth with (USD102), Gambia fifth with (USD81) and Burkina-Faso sixth with (USD75). Considering inflation rate in these countries, Ghana has the highest inflation rate of $(28 \%)$ on the average, Nigeria follows with $(20 \%)$. Burkina Faso with the lowest per capita income has the lowest inflation rate of about (3.6\%). Inflation rate in Gambia was about (9.3\%) while in Cote-d'Ivoire and Senegal; it was about (4.6\%) and $(4.0 \%)$ respectively. Examining the unemployment rate in these countries, Senegal has the highest $(10.1 \%)$, follows by Nigeria, Gambia and Ghana with $(7.5 \%),(7.1 \%)$ and $(6.7 \%)$ respectively. The unemployment rate in Cote-d'Ivoire was about (4.8\%) while Burkina-Faso has the least unemployment rate of about $(2.6 \%)$. Considering the degree of trade openness in these countries, Gambia ranked first with about $(78 \%)$ on the average, Cote-d'Ivoire second with about (77\%), Senegal third with about (66\%), Ghana fourth with about (64\%), Nigeria fifth with about (53\%) and Burkina-Faso sixth with about (38\%).

In term of the size of the money sector used as a measure of financial market development, Senegal ranked first with $(27.73 \%)$, Cote-d'Ivoire second with $(27.71 \%)$, Gambia third with $(27.69 \%)$, Nigeria fourth with $(24.45 \%)$, Ghana fifth with (22.71\%) and Burkina-Faso sixth with (20.81\%). On the basis of population growth rate in these countries, Gambia ranked first with an annual population growth rate of about $(3.39 \%)$ on the average, Senegal second with $(2.82 \%)$, Burkina-Faso third with $(2.75 \%)$, Cote-d'Ivoire fourth with $(2.73 \%)$, Ghana fifth with $(2.65 \%)$ and Nigeria sixth with $(2.60 \%)$

Table 1. Stylized Facts about the Economies of the Selected ECOWAS Countries (1981-2013).

\begin{tabular}{|c|c|c|c|c|c|c|}
\hline COUNTRY/VARIABLES OF INTEREST & COTE-D'IVOIRE & SENEGAL & GHANA & GAMBIA & NIGERIA & BURKINA FASO \\
\hline PER CAPITA INCOME IN USD & 922.727 & 694.2338 & 614.0896 & 505.1109 & 746.6932 & 343.0863 \\
\hline SIZE OF GOVERNMENT SPENDING & 11.50798 & 15.61723 & 11.36026 & 15.36018 & 9.630596 & 20.13091 \\
\hline PER CAPITA GOVT SPENDING IN USD & 103.4141 & 107.9505 & 77.88422 & 68.49739 & 69.63966 & 68.63517 \\
\hline AVERAGE EFFICIENCY & 9.879632 & 6.55724 & 9.382543 & 8.600925 & 11.84507 & 5.211837 \\
\hline DOMESTIC INVESTMENT PER CAPITA & 121.1803 & 135.4844 & 131.4463 & 81.48754 & 102.2314 & 75.0043 \\
\hline ANNUAL INFLATION RATE & 4.639181 & 4.016258 & 28.2934 & 9.346158 & 20.39206 & 3.63449 \\
\hline ANNUAL POPULATION GROWTH RATE & 2.725203 & 2.822222 & 2.650434 & 3.388988 & 2.596561 & 2.75484 \\
\hline SIZE OF MONEY SECTOR & 27.71358 & 27.72571 & 22.71312 & 27.68528 & 24.44718 & 20.80506 \\
\hline DEGREE OF TRADE OPENNESS & 0.766202 & 0.656319 & 0.640908 & 0.775656 & 0.526376 & 0.379391 \\
\hline UNEMPLOYMENT RATE & 4.75758 & 10.09394 & 6.72424 & 7.13636 & 7.55151 & 2.64242 \\
\hline
\end{tabular}

Source: Author's Own Computation using Data from World Development Indicators, 2014 Edition 


\subsection{The Magnitude of Government Spending and Economic Growth in Selected Developing ECOWAS Countries Relative to Some Selected Developed Countries (1981-2013)}

Considering the information in Table 2; some stylized facts on some selected developed countries were given side-byside with selected developing ECOWAS countries. This is given to allow easy comparison to be made concerning the magnitude of government spending and economic growth in developed countries on one side and developing countries in the ECOWAS sub-region on the other side. Based on the information presented in the table, we can appreciate the fact that per capita income and government spending are exceedingly low in the ECOWAS sub-region compare with the so-called developed countries. From the table, none of the selected countries in the ECOWAS sub-region has her per capita income up to (USD1000) on the average during the period under investigation. Whereas, New Zealand with an average per capita income of about (USD18,997) has the smallest per capita government spending of about (USD3,465) on the average. This is ten times greater than the average across the six ECOWAS countries involved in this study. Sweden with an average per capita income of about (USD33,099) has the highest government spending per capita of about (USD8,422).

Also, the United States of America with an average per capita income of about (USD32,709) has an average government spending of about (USD5,051) while Switzerland with an average per capita income of about (USD44,846) has an average government spending of about (USD4,892). Comparing these figures with their counterparts in the ECOWAS region, we can see the wide disparity both in per capita income and government spending. This is contrary to the view of many people. The general believe is that government spending is too much and hence should be cut drastically to foster economic growth. With the figures available on government spending per head of population, can we say government spending is too much in the ECOWAS sub-region? This view may be valid for developed countries where the per capita income and government spending are appreciably very high but different scenario exists in the developing ECOWAS countries. This fact conforms with Soludo's view on government spending in the Nigeria's perspective. Soludo recognized two major challenges facing the Nigeria economy. One of which is the efficiency of government spending as well as a binding budget constraint. This is what he emphasized when he made a statement

"No matter how efficient a father with a monthly salary of $\mathrm{N} 50,000$ (about USD250) is, at managing the family resources, I cannot see how he could deliver on a promise to buy a brand new Peugeot 406 for each of his three children in a year. Even with all the loopholes and waste closed, with increased efficiency per dollar spent, there is still a binding budget constraint. To deliver an efficient national transport infrastructure alone will still cost tens of billions of dollars per annum even by corruption-free, cost-effective means." (Soludo, 2015)

Government spending enters the production function as an input and hence acts as a constraint to output because of limited supply. The efficiency matter therefore has to do with getting more output from a given level of spending. Efficiency can therefore be defined as output per given level of input. In the context of this study, we defined the efficiency of government spending as the output worth of per unit of dollar spent by the government. Efficiency is gained when more output is derived from a fixed amount of government spending. Efficiency of government spending, measured as the ratio of GDP to total government spending might therefore be given consideration in modelling the behavior of government spending and economic growth.

In term of government size, there is virtually no discrepancy between developing ECOWAS countries concerned here and the so-called developed countries. For instance, government size in New Zealand is $18 \%$ on the average, Sweden is $25.6 \%$, Switzerland is $10.8 \%$, USA is $15.5 \%$, Ghana is $11.4 \%$, Senegal is $15.6 \%$, Cote d'Ivoire is $11.5 \%$, Gambia is $15.4 \%$ and Burkina Faso is $20.1 \%$. Most studies especially in the sub-region have engaged in the use of government size as a proxy to government spending and this is found to be inappropriate since it does not portray the true picture of situation in developing countries where people have little or no access to social infrastructure such as road, electricity, public health facility, and many more. Government provisions are considered to be very low considering the teeming population that are living in this economic sub-region.

Table 2. The Magnitude of Government Spending and Economic Growth in Selected Developing ECOWAS Countries Relative to some Selected Developed Countries (1981-2013).

\begin{tabular}{|c|c|c|c|c|c|c|c|c|c|c|}
\hline \multirow{2}{*}{ VARIABLES } & \multicolumn{4}{|c|}{ Developed Countries } & \multicolumn{6}{|c|}{ Developing Countries } \\
\hline & New Zealand & Sweden & Switzerland & USA & Nigeria & Ghana & Senegal & Cote d'Ivoire & Gambia & Burkina Faso \\
\hline PCGS (USD) & 3,465 & 8,422 & 4,892 & 5,051 & 70 & 78 & 108 & 103 & 68 & 69 \\
\hline PCGDP (USD) & 18,997 & 33,099 & 44,846 & 32,709 & 745 & 614 & 694 & 923 & 505 & 343 \\
\hline GSIZE (\%) & 18.0 & 25.6 & 10.8 & 15.5 & 9.6 & 11.4 & 15.6 & 11.5 & 15.4 & 20.1 \\
\hline
\end{tabular}

Source: Author's Own Computation using Data from World Development Indicators, 2014 Edition

The deficiency associated with the use of government size as a proxy of government spending can be seen in the illustration shown above. Government size failed to reflect the wide divergence which exists between developed 
countries and developing countries in the ECOWAS subregion. There is still a wide divergence in per capita income as well as per capita government spending between developed and developing ECOWAS countries. The relationship between government spending and economic growth might be sensitive to how government spending is measured. It is necessary to note despite the low per capita government spending as well per capita income in the ECOWAS sub-region, yet variation still exist on these variables across countries. It is equally observed that some other macroeconomic variables vary a little bit even within the ECOWAS sub-region. The absorption capacity varies from one county to another. On this note, this study incorporates variables such as financial market development, degree of trade openness, domestic investment per capita, population growth rate, inflation rate and efficiency variable to examine the long run equilibrium relationship and direction of causality between government spending and economic growth in six ECOWAS countries.

The remaining part of this paper include section 2 which contains literature review, section 3 which contains data and econometric methodology, section 4 which presents the empirical results while section 5 concludes the study.

\section{Literature Review}

This section reviews some relevant theories of economic growth and development as well as government spending in the economy. Based on the linear stages growth theory developed by an American economic historian by name; Walt Whitman Rostow, there is need for a massive injection of capital coupled with government intervention in order to hasten the process of industrialization in developing countries and hence stimulates economic growth. In the same vein, the Harrod-Domar growth theory concludes that growth rate of output is determined by saving (s) and capital output ratio $(R)$ which is equal to $K / Y$ i.e. $\Delta Y / Y=s / R$. In this simple model saving rate and capital output ratio are emphasized as both determinants of growth. It is a common knowledge that an impoverished individual would have little or no saving; hence government spends big in such an economy to improve the condition of the people to move from impoverished state to state of prosperity.

The balanced growth theory emphasized that the government of any underdeveloped country needs to make large investments in a number of industries simultaneously in order to enlarge the market size, increase productivity, and provide an incentive for the private sector investment. This view provides a support for the crowding-in effect of government spending as against the crowding-out effect usually claimed by some economic writers. Government can influence the activities of the private sector positively through a lot of her super provisions and packages that can step up per capita income of people given them access to participate in the production activities. This promotes the workings of the market system by enlarging the size of the market. Ragnar Nurkse, the proponent of this theory was equally of the view that the poor size of the market in developing countries perpetuates its underdeveloped state. He clarified the various determinants of the market size and puts primary focus on productivity. According to him, if the productivity levels rise in a developing country, its market size would expand and thus it can eventually become a developed country. Nurkse also asserted that developing countries lack adequate purchasing power which implies that the real income of the people is low, although it may be high nominally i.e. in monetary terms. If the money income were low, the problem could easily be overcome by expanding the money supply; however, since it is the real income, raising the supply of money will only generate inflationary pressure. Neither real output nor real investment will rise. It is to be noted that a low purchasing power implies that domestic demand for commodities is low.

According to the critical minimum efforts otherwise known as the big push theory, if a low level of equilibrium trap exists, it is argued that a critical minimum effort is required to escape from it. This view hangs on the belief that a vicious circle of poverty exists constraining development and makes it difficult to escape from it. Thus, a modest accumulation of capital may not raise incomes and hence low saving is bound to persist, but if a substantial capital accumulation can be achieved early on, income will be raised and savings generated to make the process of capital accumulation self-sustaining. According to Harvey Leibenstein, developing countries are generally characterized by vicious circle of poverty which keeps them around a low income per capita equilibrium state. The way out of this log jam is a certain critical minimum effort which is strong enough to raise the per capita income to a level at which sustained development could be maintained. The critical minimum effort in this context is relating to minimum investment required to stimulate sustainable economic growth below which will fail to raise the per capita income in the developing countries. Government effort could generate such a required investment that will stimulate economic growth in the developing countries.

Theoretically, this study relies on the strengths of these theories and largely on the endogenous growth theory as well as Wagnerian theory of increasing states activities and Keynesian theory. These theories seem to provide the framework for this study.

The endogenous growth theory attempts to model technology explicitly by looking inwardly to determinants of technology rather than assuming it to be exogenous as in Solow model. Economic growth mostly views as the outcomes of technological progress, which is essentially the ability of the economy to use up its productive resources more effectively over time.

According to Verbeck (2000), much of the ability referred to here comes from the process of learning to operate newly created production inputs in a more productive manner or more generally from learning to cope with rapid changes in the structure of production which industrial progress must imply. The endogenous growth theory made two fundamental 
assumptions namely that of increasing private capital, marginal productivity and that of positive externality associated with government spending especially on education and health. Romer (1986) encourages further studies on the impact of government spending on economic growth when he developed a model which revealed positive long run effect of government spending on economic growth.

Lukas (1988) constructed his own endogenous growth model with human capital as the driver of perpetual growth. The endogenous growth models of Barro (1990) and King and Rebelo (1990) predict that government spending and taxation will have both temporary and permanent effects on long run economic growth. An influential article by Barro (1991), appeared to present an empirical evidence favouring the view that a heavy government involvement in economic activity tend to be growth enhancing. The introduction of endogenous growth models that incorporate the government sector has led to the conclusion that fiscal policy can affect the long run growth rate of an economy (Barro and Sala-iMartin, 1992). This provides a sort of linkage between government spending and economic growth.

In models of endogenous growth, government can improve the factor allocation of the market due to market failure. As a result, total factor productivity and the accumulation of physical capital and human capital respectively can be increased. Public inputs, natural monopolies or spill-over effects are the main justifications for government provision. In theory, these publicly provided goods enter the production function so that they can boost the steady-state growth rate (Barro and Sala-i-Martin, 1992).

The Wagnerian theory of increasing state activities simply states that the development of an industrial economy would be accompanied by an increased share of government spending in gross domestic product. In relation to a developing economy, a basic assumption of the Wagner's law is that government sector growth is continuously aligned to increasing growth in the output of the economy. Government spending growth in this regard, does not only increase but increases at a faster rate than the growth of the economy's output. This in summary is what Wagner calls the law of increasing state activities. That is, growth in the economy brings about expansion in government spending but not vice versa. The law further states that a positive relationship exists between per capita income of the citizens in a country with government spending such that the income elasticity of government spending is always greater than one. Wagner goes further to say that expansion in government spending is necessitated by three main factors; one being that of administrative and protective roles of government which increase as an economy develops. The second deals with the expansion of an economy which increases government spending especially in human capital development (education and health). The third factor presupposes that technology development propels governments of developed nations to engage in certain economic services for which private sector often avoids.

Wagner also states that causality runs from national income to government spending; meaning that, there is a tendency for government spending to grow relative to some national aggregates like gross domestic product (Khan (1990), Bagdigen and Çetintaş (2003). Thus, Wagner's model is centered on the doctrine of endogenous growth since according to Afonso and Furceri (2008), government spending is treated as an outcome or an endogenous factor and not a cause of growth in national income.

On the side of Keynes and the Keynesian, government spending is an exogenous factor and policy instrument that can be used to stimulate economic growth. Government spending is seen as a cause and not the result of growth. The causality direction here runs from government spending to economic growth.

Several empirical studies have been carried out across the globe on direction of causality between government spending and economic growth. At this juncture, we would have an overview of the latest few among them.

Loizides and Vamvoukas, (2005), conducted a study using a trivariate causality test to examine the relationship between government expenditure and economic growth. Data set on Greece, United Kingdom and Ireland were used. The results of their study indicated that government spending grangercaused economic growth in all the countries involved in the study. The study found that short run and long run relationships existed for Ireland and the United Kingdom. The results also indicated that economic growth grangercauses government spending for Greece and United Kingdom, when inflation is included.

Other studies have attempted to examine the effect of government spending on economic growth. For instance, Komain and Brahmasrene, (2007) tried to find out the association between government spending and economic growth in Thailand, by employing the Granger causality test. The results revealed that government spending and economic growth are not co-integrated. Moreover, the results indicated a unidirectional relationship, as causality runs from government spending to economic growth. Also, the results of their findings indicated a significant positive effect of government spending on economic growth.

Olugbenga and Owoeye, (2007), conducted a study to find out the relationships between government spending and economic growth for a group of 30 developing countries during the period 1970-2005. The results indicated that there existed a long run relationship between government spending and economic growth. In addition, the authors observed a unidirectional causality running from government spending to economic growth for 16 out of the 30 countries involved in the study, thus supporting the Keynesian hypothesis. However, causality runs from economic growth to government spending in 10 out of the 30 countries, confirming the Wagner's law. The study also confirmed the existence of feedback relationship between government spending and economic growth for a group of four countries.

Sideris (2007) examined the direction of causality between government spending and economic growth for the Greek economy for the period 1833-1938 using standard Granger 
causality technique. The result shows that causality runs from economic growth to government spending confirming the Wagner's hypothesis for Greece. Kalam and Aziz (2009) examined the direction of causality between government spending and economic growth for Bangladesh over the period 1976-2007 using Granger causality approach. The result indicates that economic growth granger-caused government spending in Bangladesh. This result provides support for the Wagner's hypothesis in this country. They further established that real GDP and per capita GDP granger caused total government spending while population size served as a stimulus for government spending both in the short and long runs for the economy of Bangladesh.

Olomola (2004) examined the causal relationship between national income and government spending in Nigeria between 1970 and 2001 using cointegration procedure and VECM. The result shows that economic growth captured by GNP per capita granger-caused government spending, both in the short and long run. This result validates the Wagner's hypothesis for the Nigerian economy. Akinlo (2013) investigated the nexus between economic growth and government spending in Nigeria over the period 1961-2009 in multivariate framework incorporating population size variable. The result provides support for Wagner's law in Nigeria. The study also established long run relationship among real GDP, real government spending and population size.

Frimpong and Oteng-Abaiye (2009) attempted to find out the direction of causality between economic growth and government spending in three countries in the eco-zone subgroup of ECOWAS called West African Monetary Zone (WAMZ) namely; Gambia, Ghana and Nigeria. The study aimed at testing whether the data in these countries would validate the Wagner's hypothesis or would be in line with the Keynesian view. The result found no support for Wagner's nor Keynesian view.

Yaya (2015) revisited Wagner's law for selected African countries using Frequency Domain Causality approach. The finding reveals that Wagner's law hold in the short, medium and long run for Ghana and Nigeria. The opposite view is supported for Gabon and Senegal. The study found bidirectional causality in the case of Burkina Faso in the short, medium and long run. Conversely, there is no evidence in support of Wagner's law or Keynesian view in the short, medium and long run in the case of Cote d'Ivoire and Kenya.

Table 3 revealed the summary of the empirical studies on the long run equilibrium relationship and direction of causality between government spending and economic growth across the globe.

Table 3. Summary of Empirical Studies on Long Run Relationship and Direction of Causality between Government Spending and Economic Growth.

\begin{tabular}{|c|c|c|c|c|c|}
\hline Names of Authors & Continent/Region & Country/ies studied & Period of coverage & Long-run Relation & Causality Relation \\
\hline Islam (2001) & \multirow{9}{*}{ America } & $\begin{array}{l}\text { United States } \\
9 \text { Carribean Countries }\end{array}$ & 1929-1996 & Support & $\mathrm{GDP} \Rightarrow \mathrm{GS}$ \\
\hline \multirow{8}{*}{ Iyare and Lord(2004) } & & Belize & $1950-2000$ & \multirow{8}{*}{$\begin{array}{l}\text { Support for } 3 \text { out of } \\
\text { the } 9 \text { countries }\end{array}$} & $\mathrm{GDP} \Rightarrow \mathrm{GS}$ \\
\hline & & Grenada & $1950-2000$ & & $\mathrm{GDP} \Rightarrow \mathrm{GS}$ \\
\hline & & Antigua Barbados & $1950-2000$ & & $\mathrm{GDP} \Rightarrow \mathrm{GS}$ \\
\hline & & St. Kitts and Nevis & $1950-2000$ & & $\mathrm{GDP} \Rightarrow \mathrm{GS}$ \\
\hline & & St. Lucia & $1950-2000$ & & $\mathrm{GDP} \Rightarrow \mathrm{GS}$ \\
\hline & & Tobago & $1950-2000$ & & $\mathrm{GDP} \Rightarrow \mathrm{GS}$ \\
\hline & & Guyana & $1950-2000$ & & $\mathrm{GDP} \Longleftarrow \mathrm{GS}$ \\
\hline & & Jamaica & $1950-2000$ & & No causality \\
\hline Ahsan et al.(1996) & America & Canada & $1952-1988$ & Support & $\mathrm{GDP} \Rightarrow \mathrm{GS}$ \\
\hline Yay andTastan (2009) & Europe & Turkey & $1950-2004$ & Support & $\mathrm{GDP} \Leftrightarrow \mathrm{GS}$ \\
\hline Sideris (2007) & Europe & Greece & $1832-1938$ & Support & $\mathrm{GDP} \Rightarrow \mathrm{GS}$ \\
\hline Kumar etal.(2009) & Europe & New Zealand & $1960-2007$ & No support & $\mathrm{GDP} \Rightarrow \mathrm{GS}$ \\
\hline Haliciogglu(2005) & Europe & Turkey & $1960-2000$ & Support & $\mathrm{GDP} \Leftrightarrow \mathrm{GS}$ \\
\hline \multirow[t]{3}{*}{ Bagdigen and Cetintas (2003) } & \multirow[t]{3}{*}{ Europe } & Turkey & $1950-2000$ & \multirow[t]{3}{*}{ No Support } & No causality \\
\hline & & Denmark & $1850-1913$ & & $\mathrm{GDP} \Rightarrow \mathrm{GS}$ \\
\hline & & Germany & $1850-1913$ & & $\mathrm{GDP} \Rightarrow \mathrm{GS}$ \\
\hline \multirow{4}{*}{ Thornton (1999) } & \multirow{4}{*}{ Europe } & Italy & $1850-1913$ & \multirow{4}{*}{$\begin{array}{l}\text { Support for } 5 \\
\text { countries }\end{array}$} & $\mathrm{GDP} \Leftrightarrow \mathrm{GS}$ \\
\hline & & Norway & $1850-1913$ & & $\mathrm{GDP} \Rightarrow \mathrm{GS}$ \\
\hline & & Sweden & $1850-1913$ & & $\mathrm{GDP} \Rightarrow \mathrm{GS}$ \\
\hline & & United Kingdom & $1850-1913$ & & $\mathrm{GDP} \Leftrightarrow \mathrm{GS}$ \\
\hline \multirow{3}{*}{$\begin{array}{l}\text { Abu-Bader and Abu-Quarn } \\
(2003)\end{array}$} & \multirow{3}{*}{ Africa/Middle-East } & Egypt & 1963-1998 & No support & No causality \\
\hline & & Israel & 1963-1998 & Support & $\mathrm{GDP} \Leftrightarrow \mathrm{GS}$ \\
\hline & & Syria & 1963-1998 & Support & $\mathrm{GDP} \Leftrightarrow \mathrm{GS}$ \\
\hline \multirow{5}{*}{ Dogan and Tang (2006) } & \multirow{5}{*}{ South-East Asia } & Indonesia & $1960-2002$ & Support & No causality \\
\hline & & Malaysia & 1960-2002 & No support & No causality \\
\hline & & Singapore & $1960-2002$ & No support & No causality \\
\hline & & Thailand & $1960-2002$ & No support & No causality \\
\hline & & Philippines & 1960-2002 & No support & $\mathrm{GDP} \Leftarrow \mathrm{GS}$ \\
\hline Huang (2006) & Asia & China & $1979-2002$ & No Support & No causality \\
\hline
\end{tabular}




\begin{tabular}{|c|c|c|c|c|c|}
\hline Names of Authors & Continent/Region & Country/ies studied & Period of coverage & Long-run Relation & Causality Relation \\
\hline \multirow{5}{*}{ Peters (2007) } & \multirow{5}{*}{ Europe \& America } & Taiwan & $1979-2002$ & & \\
\hline & & USA & & Support & $\mathrm{GDP} \Rightarrow \mathrm{GS}$ \\
\hline & & Barbados & & Support & $\mathrm{GDP} \Rightarrow \mathrm{GS}$ \\
\hline & & Haiti & & Support & $\mathrm{GDP} \Longrightarrow \mathrm{GS}$ \\
\hline & & Thailand & & Support & $\mathrm{GDP} \Rightarrow \mathrm{GS}$ \\
\hline Lamartina and Zaghini (2008) & & 23 OECD countries & $1970-2006$ & Support & $\mathrm{GDP} \Rightarrow \mathrm{GS}$ \\
\hline Olomola (2004) & Africa & Nigeria (ECOWAS) & $1970-2001$ & Support & $\mathrm{GDP} \Rightarrow \mathrm{GS}$ \\
\hline $\begin{array}{l}\text { Frimpong and Oteng-Abaiye } \\
\text { (2009) }\end{array}$ & Africa & $\begin{array}{l}\text { Gambia, Ghana, } \\
\text { Nigeria } \\
\text { ECOWAS(WAMZ) }\end{array}$ & & No Support & $\begin{array}{l}\text { No causality in any } \\
\text { of the three } \\
\text { countries }\end{array}$ \\
\hline Sideris (2007) & Europe & Greece & $1833-1938$ & Support & $\mathrm{GDP} \Rightarrow \mathrm{GS}$ \\
\hline Webber et al. (2010) & Europe & $\begin{array}{l}\text { New Zealand } \\
\text { China, Taiwan, Hong- }\end{array}$ & $1960-2007$ & Support & $\mathrm{GDP} \Rightarrow \mathrm{GS}$ \\
\hline Kumar (2009) & Asia & $\begin{array}{l}\text { Kong, Japan, South } \\
\text { Korea }\end{array}$ & $1960-2007$ & Support & $\mathrm{GDP} \Rightarrow \mathrm{GS}$ \\
\hline Magazzino (2010b) & Europe & E-U countries & 1970-2009 & $\begin{array}{l}\text { Support for } 7 \text { out } 0 \mathrm{f} \\
11 \text { countries }\end{array}$ & $\begin{array}{l}\text { No causality in } 5 \\
\text { out of } 11 \text { countries }\end{array}$ \\
\hline Verma and Arora (2010) & Asia & India & $1950-2008$ & Support & No causality \\
\hline Kalam and Aziz (2009) & Asia & Bangladesh & $1976-2007$ & Support & $\mathrm{GDP} \Rightarrow \mathrm{GS}$ \\
\hline Abdullah and Maamor (2010) & Asia & Malaysia & $1970-2007$ & Support & $\mathrm{GDP} \Rightarrow \mathrm{GS}$ \\
\hline Chimobi (2009) & Africa & Nigeria (ECOWAS) & $1970-2006$ & No support & $\mathrm{GDP} \Leftarrow \mathrm{GS}$ \\
\hline Babatunde (2007) & Africa & Nigeria (ECOWAS) & $1970-2005$ & No support & $\mathrm{GDP} \Leftarrow \mathrm{GS}$ \\
\hline Gabriel et al., (2014) & Africa & South Africa & $1990-2010$ & Support & \\
\hline Akinlo (2013) & Africa & Nigeria (ECOWAS) & 1961-2009 & Support & $\mathrm{GDP} \Longrightarrow \mathrm{GS}$ \\
\hline Olusi and Dada (2015) & $\begin{array}{l}\text { Developing } \\
\text { Countries }\end{array}$ & $\begin{array}{l}\text { Nigeria, Saudi-Arabia } \\
\text { \&Indonesia }\end{array}$ & $1981-2013$ & Support & \\
\hline \multirow{3}{*}{ Yaya (2015) } & \multirow{3}{*}{ Africa } & Ghana and Nigeria & $1965(80)-2013$ & Support & $\mathrm{GDP} \Rightarrow \mathrm{GS}$ \\
\hline & & Gabon and Senegal & $1965-2013$ & Support & $\mathrm{GDP} \Leftarrow \mathrm{GS}$ \\
\hline & & Burkina Faso & $1965-2013$ & Support & $\mathrm{GDP} \Leftrightarrow \mathrm{GS}$ \\
\hline Ghorbani and Zarea (2013) & Middle East & Iran & $1960-2000$ & Support & $\mathrm{GDP} \Rightarrow \mathrm{GS}$ \\
\hline Mutuku and Kimani (2012) & Africa & Kenya & $1960-2009$ & Support & $\mathrm{GDP} \Rightarrow \mathrm{GS}$ \\
\hline Lesotho (2013) & Africa & Lesotho & $1980-2010$ & Support & \\
\hline Muse and Alimi (2013) & Africa & $\begin{array}{l}\text { Nigeria (ECOWAS) } \\
\text { Colombia, Chile, }\end{array}$ & $1961-2011$ & No Support & $\mathrm{GDP} \Leftarrow \mathrm{GS}$ \\
\hline Grullon (2014) & Latin America & $\begin{array}{l}\text { Paraguay, Honduras, } \\
\text { Panama }\end{array}$ & 1980-2012 & Support & $\mathrm{GDP} \Rightarrow \mathrm{GS}$ \\
\hline Rauf (2012) & Asia & Pakistan & 1979-2009 & No support & No causality \\
\hline Srinivasan (2013) & Asia & India & & Support & $\mathrm{GDP} \Rightarrow \mathrm{GS}$ \\
\hline Gadinabokao and Daw (2013) & Africa & South Africa & $1980-2011$ & Support & \\
\hline Ghali and Al-Shamsi (1997) & Middle East & UAE & & Support & $\mathrm{GDP} \Leftarrow \mathrm{GS}$ \\
\hline \multirow[t]{2}{*}{ Ranjan and Sharma (2008) } & \multirow[t]{2}{*}{ Asia } & India & $1950-2007$ & Support & \multirow[t]{2}{*}{$\mathrm{GDP} \Leftarrow \mathrm{GS}$} \\
\hline & & Morocco & $1970-2002$ & Support & \\
\hline \multirow[t]{2}{*}{ Mansouri (2008) } & \multirow[t]{2}{*}{ Africa } & Tunisia & $1972-2002$ & Support & \\
\hline & & Egypt & $1975-2002$ & Support & \\
\hline Dada and Oguntegbe (2013) & Africa & Nigeria (ECOWAS & $1961-2011$ & Support & $\mathrm{GDP} \Rightarrow \mathrm{GS}$ \\
\hline Richter and Paparas (2012) & Europe & Greece & $1833-2010$ & Support & $\mathrm{GDP} \Rightarrow \mathrm{GS}$ \\
\hline Ghartey (2007) & Africa & Ghana (ECOWAS) & $1965-2004$ & Support & $\mathrm{GDP} \Rightarrow \mathrm{GS}$ \\
\hline Ziramba (2008) & Africa & South Africa & $1960-2006$ & Support & $\mathrm{GDP} \Leftrightarrow \mathrm{GS}$ \\
\hline Yilgor et al (2012) & Asia & Turkey & $1980-2010$ & Support & $\mathrm{GDP} \Leftarrow \mathrm{GS}$ \\
\hline Ebaidalla (2013), & Africa & Sudan & $1970-2008$ & Support & $\mathrm{GDP} \Leftarrow \mathrm{GS}$ \\
\hline Abu-Eideh (2015) & Middle East & Palestine & $1994-2013$ & Support & $\mathrm{GDP} \Leftrightarrow \mathrm{GS}$ \\
\hline
\end{tabular}

\subsection{Gap in Literature}

The review of theoretical and empirical literature on the relationship between government spending and economic growth has revealed some clear cut relationship between the two variables. The early part of the review focused on the theoretical literature followed by a brief review of empirical literature involving some studies on developed countries, developing countries outside the ECOWAS sub-region as well as developing countries within the ECOWAS subregion.

In this review, it is observed that two popular views are pertinent on the relationship between government spending and economic growth. The first are those that hold the pessimistic view and hence move against large government that it is detrimental to growth and therefore suggest a fiscal consolidation especially in countries where there is high debt burden and fiscal imbalances. This school of thought is pessimistic about the long run equilibrium relation and causality between government spending and economic growth, hence kicked against large government.

The second are those who hold an optimistic view and hence move in favour of large government that it enhances growth and therefore calling for fiscal space. This school of 
thought is optimistic about the long run equilibrium relation and causality between government spending and economic growth, hence, provided a support for large government. These opposing views exist both in theory and empirics on government spending and economic growth across countries and regions. There is generally a lack of consensus both in theories and empirics on government spending and economic growth.

Also, one line of argument concludes that government spending is an endogenous factor which is determined by the growth of national income suggesting unidirectional causality running from economic growth to government spending. Another line of argument concludes that government spending is an exogenous factor and a policy instrument which determines economic growth suggesting a unidirectional causality running from government spending to economic growth. These two popular views also extend to those who found support for the existence of long run equilibrium relationship between government spending and economic growth and those who found no support for this hypothesis.

It is also observed that the measure of government spending is widely in favour of government size measured as total government spending as a share of GDP. The appropriateness of this measure has been questioned. Inappropriate econometric application has equally been noted.

More importantly, studies given attention to efficiency of government spending in this review are scarce. Empirical literature is characterized with mixed and contentious findings. Also, it suffered from simultaneous inclusion of some key variables that may serve as additional sources of long run equilibrium relation and causality. We also noticed variations in measurement of key variables and the framework adopted. Studies whose focus is to resolve these divergent views are also found to be sparse particularly in developing West African countries in the ECOWAS subregion. These observed deficiencies in prior studies create the gap which this study came up to fill with the use of more appropriate econometric techniques.

\subsection{Presentation of the Schematic Models Relating Government Spending with Each of the Key Macroeconomic Aggregates}

Government spending has various components through which it affects the economy. A change in any of these components would definitely bring about a change in total government spending. The major components of government spending include health, agriculture, education, defence and internal security, social security and welfare, social infrastructure such as electricity, road, water, pipeline, railway, waterway, airway, etc. Whenever there is any change either an increase or a decrease in any of these components, the total government spending would also be affected either upward or downward. Government spending affects the economy of a country through these various structures of government spending highlighted in the schematic models presented in Figures 1-4.

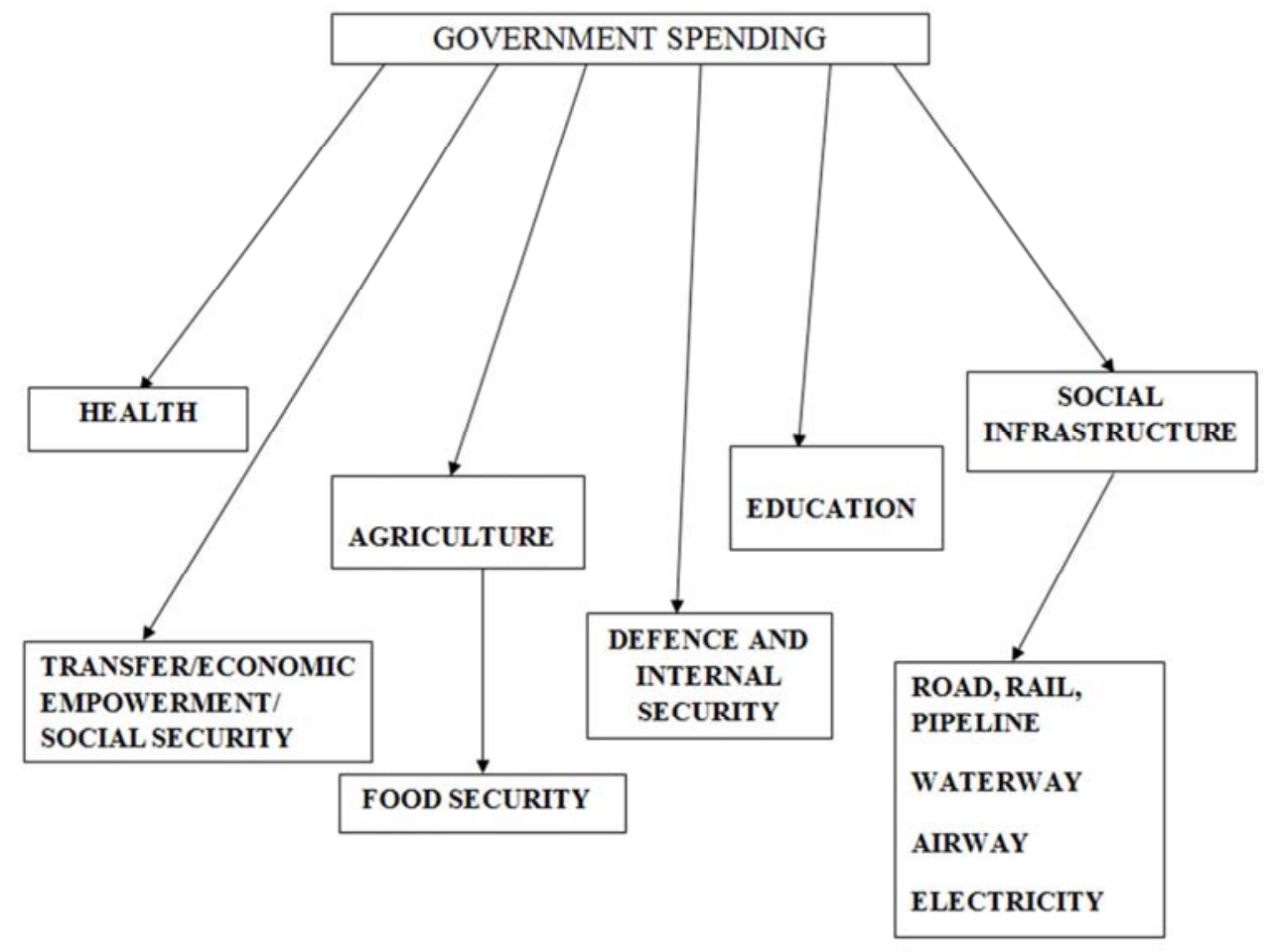

Source: Self-constructed (Field Work, 2016)

Figure 2. Channels through which Government Spending can affect Output Growth in an Economy. 


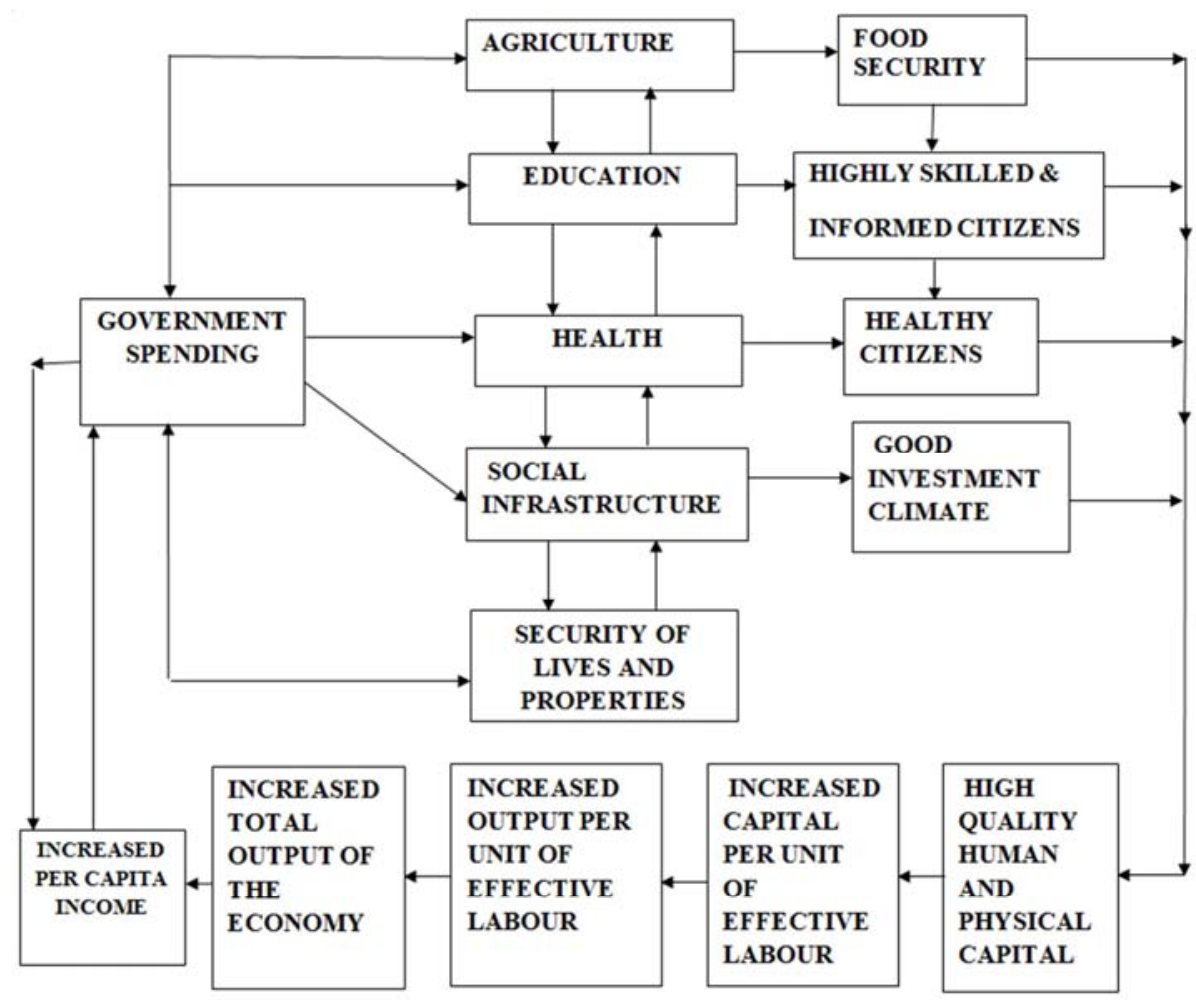

Source: Self-constructed (Field Work, 2016)

Figure 3. Transmission Mechanisms and Interconnectivity of various Components of Government Spending.

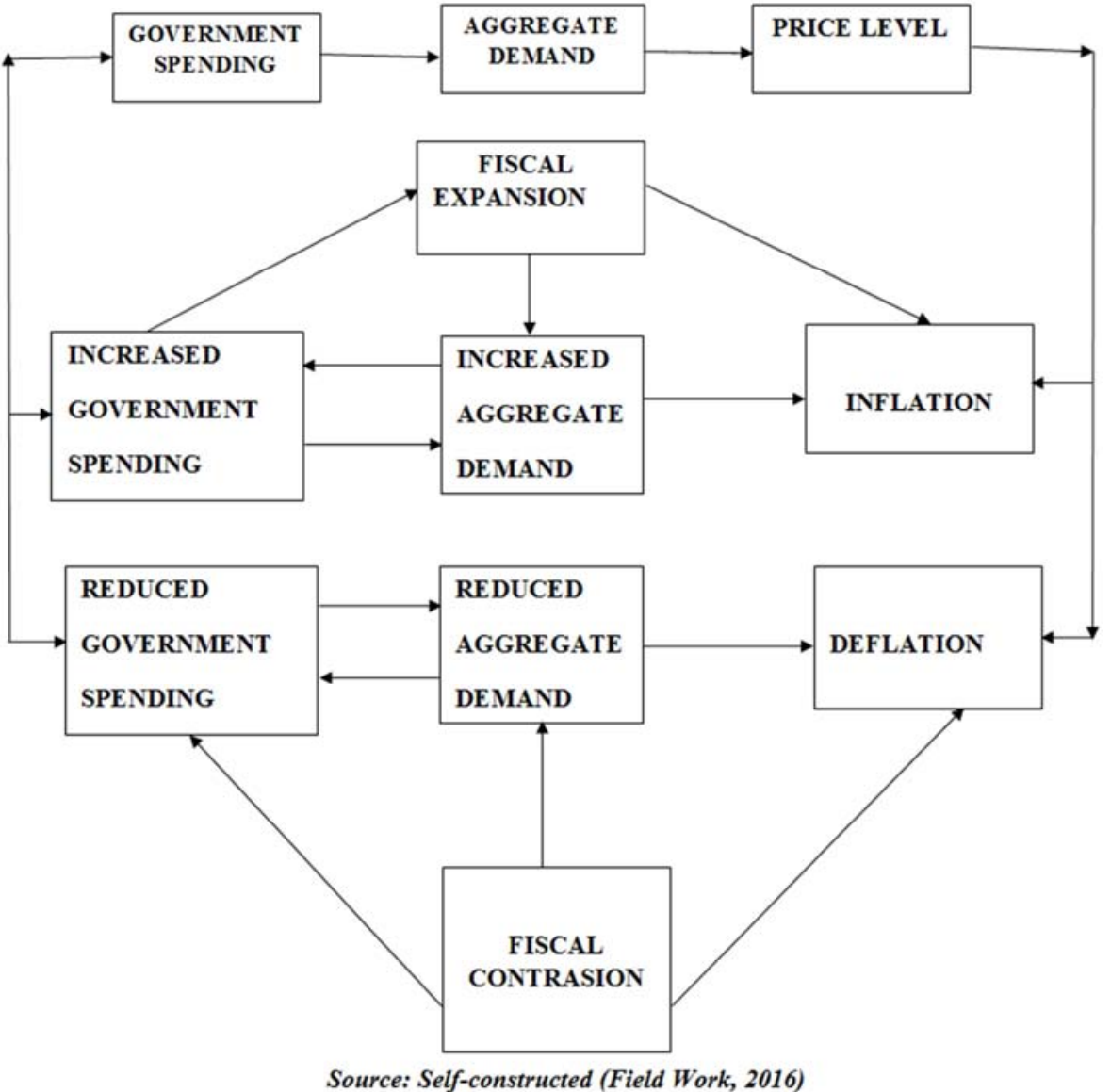

Figure 4. Channels through which Government Spending affects Prices of Goods and Services in the Economy. 


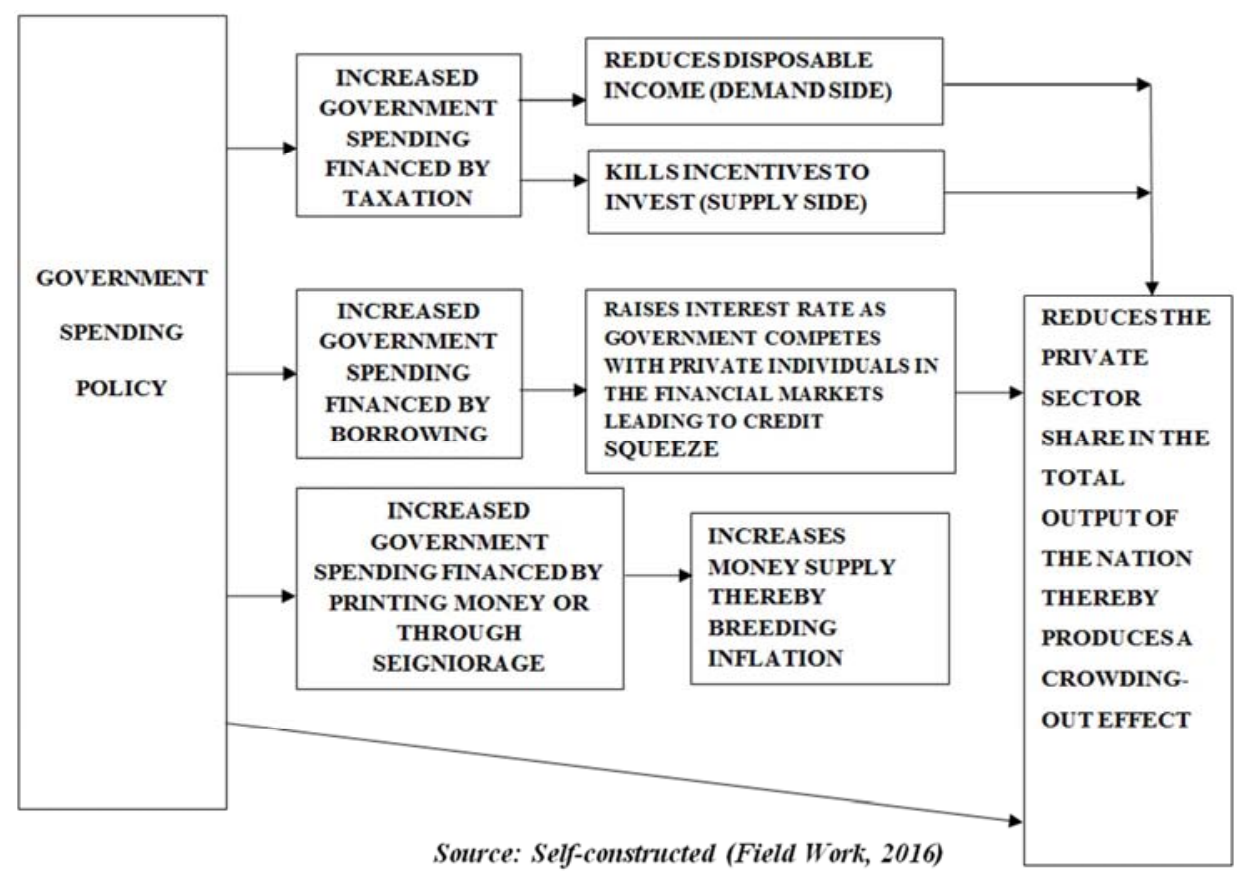

Figure 5. Channels through which Government Spending affects Private Consumption in the Economy.

\section{Data and Econometric Methodology}

The main source of data for this study is the World Development Indicators (WDI), 2014 edition. Other sources used to augment this include Penn World Tables (PWT) version 7.1 as used in (Heston et al., 2002), International Financial Statistics (IFS), World Bank Group (WBG), CBN and World Bank documentations. One of the key variables in this study is gross domestic product measured in per capita term which was used as a measure of economic growth. Government spending was measured both in per capita term as well as the total government spending as a share of GDP. This was obtained for each country. We also computed government efficiency variable for each country from aggregate government spending and GDP in current US dollar. This is measured as total GDP in current US dollar divided by total government spending also in current US dollar. This could be interpreted as the worth of output per unit of dollar spent by the government. Efficiency is gained when more output is obtained from a fixed amount of input.

Government spending and gross domestic product expressed in per capita term serve as core variables in this study. Other variables entered our bivariate models as fixed exogenous. Such variables include the degree of trade openness which is measured as the sum of exports and imports divided by GDP and domestic investment per capita measured as gross capital formation divided by population. The consumer price index with 2010 base year was obtained for each country. This was expressed in log form to proxy inflation rate in each country. The alternative to this measure, which is the annual inflation rate was equally obtained for each country and finally used as alternative to log of CPI. CPI measures the rate at which the prices of consumer goods and services change over time. Also, broad money (M2) expressed as a ratio of GDP was used to capture the size of the money sector in each of the participating countries. This is also used to represent the financial market development variable in each country. Also, population growth rate was obtained for each country and it entered the models as exogenous variable. Total population for each country was also sourced which enabled us to compute the per capita GDP, per capita government spending and domestic investment per capita for each of the participating counties.

\subsection{Our Models}

In models of endogenous growth, government can improve the factor allocation of the market due to market failure. As a result, private factor productivity and the accumulation of private capital can be increased. Public inputs, natural monopolies or spill-over effects are the main justifications for government provision. In theory, these publicly provided goods enter the production function so that they can boost the steady-state growth rate. Barro and Sala-i-Martin, (1992) have provided a clear theoretical exposition of this view.

The Solow growth model emphasized that variation in capital accumulation and exogenous technology is responsible for differences in the growth rate of output across economies in the world over. To enhance the growth rate of output, countries should continue the process of accelerating capital accumulation and technological progress. In this study capital is decomposed into two namely the private capital and the public capital.

The law of motion of capital thus is given by

$$
\dot{k}=\frac{K}{A L}-k n-k g
$$

But $K=s Y-\delta \mathrm{K}$ 


$$
\dot{k}=\frac{s Y-\delta \mathrm{K}}{A L}-k n-k g
$$

This can be simplified as

$$
\dot{k}=\mathrm{sy}-\delta \mathrm{k}-k n-k g
$$

Where

$\mathrm{s}=$ saving rate which is the sum of private and public saving

$\mathrm{n}=$ population growth rate

$\mathrm{g}=$ growth rate of technology

$\delta=$ depreciation rate

By factorizing equation (3)

$$
\dot{k}=\mathrm{sy}-(n+g+\delta) k
$$

At the steady state, $k=k^{*}, \dot{k}=0$, hence we have

$$
\begin{gathered}
\text { sy }=(n+g+\delta) k^{*} \\
k^{*}=\frac{s y}{n+g+\delta}
\end{gathered}
$$

But $y=k^{\alpha}$, and $k \rightarrow k^{*}$ thus

$$
k^{*}=\frac{s k^{* \alpha}}{n+g+\delta}
$$

Dividing both sides of equation (7) by $k^{* \alpha}$, we have

$$
\frac{k^{*}}{k^{* \alpha}}=\frac{s}{n+g+\delta}
$$

Applying factorization and laws of indices to equation (8), we have

$$
k^{*(1-\alpha)}=\frac{s}{n+g+\delta}
$$

We obtain the steady state capital stock as

$$
k^{*}=\left(\frac{s}{n+g+\delta}\right)^{\frac{1}{1-\alpha}}
$$

The output per unit of effective capital is given by

$$
y=A k^{\alpha}
$$

At the steady state, $k \rightarrow k^{*}, y \rightarrow y^{*}$ therefore equation (11) becomes

$$
y^{*}=A k^{* \alpha}
$$

By substituting equation (10) into equation (12), we obtain the steady state output as

$$
y^{*}=A\left(\frac{s}{n+g+\delta}\right)^{\frac{\alpha}{1-\alpha}}
$$

By linearizing equation (13), we have

$$
\operatorname{In} y^{*}=\operatorname{In} A+\frac{\alpha}{1-\alpha} \operatorname{In} s-\frac{\alpha}{1-\alpha} \operatorname{In}(n+g+\delta)
$$

But $A=A o e^{g t}$, hence equation (14) becomes

$$
\operatorname{In} y^{*}=\operatorname{In} A_{0}+\operatorname{In} e^{g t}+\frac{\alpha}{1-\alpha} \operatorname{In} s-\frac{\alpha}{1-\alpha} \operatorname{In}(n+g+\delta)
$$

Taking partial derivative of eqn. (15) with respect to saving rate which is otherwise known as the rate of capital accumulation, we now have

$$
\left(\frac{\delta}{\delta s}\right) \operatorname{In}^{*}=\left(\frac{\delta}{\delta s}\right) \frac{\alpha}{1-\alpha} \operatorname{In} s
$$

But as $y=y^{*},\left(\frac{\delta}{\delta \operatorname{Ins}}\right) \operatorname{In} y=0$, which implies that changes in the rate of capital accumulation would no longer have any effect on the rate of economic growth.

In this simple model, a rise in the saving rate leads to an increase in the rate of economic growth. Equally, an increase in the use of capital relative to output reduces growth because of the fact that more capital will be needed to produce a given level of output. Holding all other factors constant (ceteris paribus), the output generated by each additional unit of capital will eventually fall, depicting the law of diminishing returns. An increase in the depreciation rate also reduces economic growth, because it reduces the amount of saving available for net investment to replace the worn-out capital. Counting on the issue of conditional convergence, the model predicts convergence in growth rates on the premise that poor countries will grow faster than rich countries.

In neoclassical growth models, the long run growth rate is exogenously determined i.e. it is determined outside the model. A common prediction of these models is that an economy will always converge towards a steady state rate of growth, which depends only on the rate of technological progress (g) and the rate of labour force growth (n). A country with higher saving rate will experience faster growth. However, in the very long-run capital accumulation appears to be less significant than technological innovation in the Solow model. However, technological progress, measured as total factor productivity is determined exogenously in the Solow growth model. This is simply due to the fact that the sources of this residual or technological change remain unexplained in the neoclassical economic growth framework as presented in Solow growth model. This short-coming led to the emergence of endogenous growth model which shares the view that improvement in output can be traced to a faster pace of innovation and extra investment in human capital.

The endogenous growth theory through this mechanism was able to reduce the limitations of the neoclassical growth model by allowing increasing returns to scale through endogenous technological progress which could be traced to human capital accumulation. Even though Arrow and Uzawa pioneered such work in the 1960s (Arrow, 1962; Uzawa, 1965), it was not until the 1990s that diverse ideas have been expressed into formal models in the neoclassical tradition. Endogenous growth theorists also emphasize the need for government and private sector institutions as well as markets, which nurture innovation and provide incentives to bring out creativity in individuals. There is also a central role for knowledge and skill as determinants of economic growth. Therefore empirical literature has witnessed a paradigm shift from exogenous growth model to the endogenous growth model which believes that there is increasing return to scale. This got motivation from the seminar work by Romer's 
(1986) and Lucas's (1988). Within this framework of analysis, three significant sources of growth have been identified; these include new knowledge (Romer, 1990; Grossman and Helpman, 1991), innovation (Aghion and Howitt, 1992) and public infrastructure (Barro, 1990). Contrary to the neoclassical view, policies are deemed to play a crucial and permanent role in advancing long run economic growth. As a result, convergence would not occur under the endogenous growth theory. This is owing to the fact that there are increasing returns to scale.

Hence, the condition that $y=y^{*}$ with $\left(\frac{\delta}{\delta s}\right)$ Iny $=0$ becomes an evasive.

Changes in the rate of capital accumulation will continue to bring about changes in the rate of economic growth. Equation (16) thus implies that the rate of change in the growth rate of output is determined by the rate of change in the saving rate that is the rate of change of capital accumulation across countries. It is a common knowledge that accumulation of public capital will induce the aggregate capital in the production function (Olusi and Dada, 2015).

The study got motivation from the production function of the form

$$
q_{t}=A f(\mathrm{k})
$$

Where

$k$ is the aggregate capital in the economy. Any change in the component of this aggregate will definitely cause a change in it. Also, it should be noted that an increase in the supply of public capital as a component of $k$ influences the remaining components positively. This is based on the assumption of complementarity of public capital as against substitutability. Otto and Voss (1994) provided some empirical evidence that causality flows from public capital to private production. An increase in public capital would raise the level of aggregate capital in the production function and this makes the capital accumulation process a more sustainable one. The aggregate production function therefore become

Equation (17) can be expressed as

$$
q_{t}=A k_{t}^{\alpha}
$$

By decomposing aggregate capital into two namely other components of aggregate capital one side and public capital on the other side, equation (18) thus become

$$
q_{t}=A_{t} k_{1 t}^{\alpha} k_{2 t}^{1-\alpha}
$$

Where

$k_{1 t}$ is the other components of aggregate capital in the production function other than public capital during the time $t$

$k_{2 t}$ is the amount of public capital in the production function during the time $t$

$\alpha$ is the contribution of other components of aggregate capital to the total output

$1-\alpha$ is the contribution of public capital to the total output

$A_{t}$ is the remaining output that are not attributed to $k_{1 t}$ and $k_{2 t}$ during the period $t$
According to Lipsey (2001), the effects of variables such as inflation rate, financial market development and degree of trade openness on growth, possibly operates through total factor productivity $\left(A_{t}\right)$

$$
A_{t}=f(T R O P N, I N F R T, M 2 P C G D P, H)
$$

Substituting equation (20) into equation (19), we have

$$
q_{t}=\operatorname{DTROPN}^{\theta}{ }_{\text {INFRT }}{ }^{\sigma} M 2 P C G D P^{\varphi} K_{1 t}{ }^{\alpha} K_{2 t}{ }^{\beta} H(21)
$$

Suppose $K_{2 t}$ increased by say $\Delta K_{2 t}$, this would increase the aggregate capital in the production function. Such increase would have positive effect on the aggregate output in the production function.

By linearizing equation (21), we have

$$
\begin{array}{r}
\operatorname{In} q_{t}=\mathrm{h}_{0}+\theta \operatorname{InDTROPN}+\sigma \operatorname{InINFRT}+\varphi \operatorname{InM} 2 P C G D P+ \\
\alpha \operatorname{In} K_{1 t}+\beta \operatorname{In} K_{2 t}
\end{array}
$$

Where $\theta, \sigma, \varphi, \alpha, \beta$ are constant elasticity coefficients of output with respect to DTROPN, INFRT, M2PCGDP, $K_{1 t}$ and $K_{2 t}$.

$\mathrm{h}_{0}=\operatorname{InH}$, it represents a constant parameter, $q_{t}$ represents economic growth.

To capture the objective of long run equilibrium relationship between government spending and economic growth, the study employed the autoregressive distributed lag popularly called the ARDL approach.

In conjunction with this is the use of error correction model (ECM) to determine the short run dynamics in the model of government spending and economic growth in the selected ECOWAS countries.

The long run equilibrium relation thus was examined using an ARDL specification of the form

$$
\begin{array}{r}
\Delta Q=\phi_{0}+\phi_{1} Q_{t-1}+\phi_{2} R_{t-1}+\phi_{3} E_{t-1}+\sum_{i=1}^{p} \lambda_{i} \Delta \boldsymbol{Q}_{t-\boldsymbol{i}}+ \\
\sum_{j=0}^{p} \psi_{i} \Delta \boldsymbol{R}_{t-j}+\sum_{s=0}^{p} \Omega_{s} \Delta \boldsymbol{E}_{t-s}+\boldsymbol{\epsilon}_{\boldsymbol{i}}
\end{array}
$$

Where,

$Q=$ natural logarithm of GDP

$R=$ government spending variable

$E=$ control variable

$\phi_{0}=$ the drift component

$\epsilon_{i}$

$=$ error terms which are assumed to be white noise processes.

$\Delta=$ the first difference operator

The ARDL approach estimates $(\boldsymbol{p}+\mathbf{1})^{\boldsymbol{k}}$ number of regression in order to obtain the optimal lag for each variable in the model.

From $(p+1)^{k}$

$\mathrm{p}=$ the optimal lag to be used

$\mathrm{k}=$ the number of variables in the model

In order to ensure the absence of serial correlation in the estimated residual, we allow Schwarz-Bayesian Criteria (SC) to select the optimal lag of the first difference regression. This criterion is widely believed as a criterion which selects the smallest lag length to ensure a parsimonious model.

Following Pesaran et al (2001), we use an F-test to test for the joint significance of the coefficients of lagged variables in 
their level form as appeared in equation (22) to confirm the existence of long run relationship.

The null hypothesis to be tested is shown as follows

$$
H_{0}: \boldsymbol{\phi}_{1}=\boldsymbol{\phi}_{2}=\boldsymbol{\phi}_{3}=\mathbf{0}
$$

The non-rejection of this hypothesis implies that there is no evidence in support of long run relationship

The alternative hypothesis is denoted by $H_{1}$ and it is given by

$$
H_{1}: \boldsymbol{\phi}_{1} \neq \boldsymbol{\phi}_{2} \neq \boldsymbol{\phi}_{3} \neq \mathbf{0}
$$

Once $H_{0}$ is rejected, $H_{1}$ automatically become valid. This implies that there is evidence in support of long run relationship. There are two asymptotic critical value bounds which provide a test for co-integration when the independent variables are $\mathrm{I}(\mathrm{d})$ with $\mathrm{d}$ lies in the range 0 and 1 , that is $0 \leq$ $\mathrm{d} \leq 1$. We assumed a lower bound when the independent variables are $\mathrm{I}(0)$. We assumed an upper bound when the explanatory variables are said to be $\mathrm{I}(1)$.

The decision rule is based on the F-value. If F-value is greater than upper critical bound, It is ruled that a long run relationship exists without minding the order of integration of the variables involved that is whether $\mathrm{I}(0)$ or $\mathrm{I}(1)$. On the other hand, if F-value is less than the lower critical bounds, then we do not reject the null hypothesis of no co-integration. However, if F-value falls within these two F-values, the inference becomes inconclusive.

After a due confirmation of long run equilibrium relationship, we therefore explored further to capture the short run dynamics characterizing our models. This is done by estimating the error correction version of the modified ARDL model of the form

$$
\begin{aligned}
\Delta \boldsymbol{Q}_{\boldsymbol{t}}=\sum_{h=1}^{p_{1}} \lambda_{h} \Delta \boldsymbol{Q}_{\boldsymbol{t}-\boldsymbol{h}}+ & \sum_{j=1}^{p_{2}} \psi_{j} \Delta \boldsymbol{R}_{\boldsymbol{t}-\boldsymbol{j}}+\sum_{s=1}^{p_{3}} \Omega_{s} \Delta \boldsymbol{E}_{\boldsymbol{t}-\boldsymbol{s}}+ \\
\boldsymbol{\gamma} \boldsymbol{E} \boldsymbol{C} \boldsymbol{M}_{\boldsymbol{t}-\mathbf{1}}+\epsilon_{\boldsymbol{t}} & (24)
\end{aligned}
$$

All variables appear in the model in first differences with the inclusion of the error correction term lag one period. The co-efficient of the error correction term ' $\gamma$ ' by apriori expectation should be negatively signed and must be significant. It shows the speed of adjustment on yearly basis to long run equilibrium after a short run deviation. This uncovers the short run dynamic relation between government spending and economic growth.

In order to ensure the goodness of fit of the ARDL model and all other models previously specified for estimation purposes, the study conducted appropriate diagnostic and stability tests. The diagnostic test examines the functional form of the serial correlation, normality and heteroscedasticity of the models.

The stability test is conducted by employing the correllogram of residuals (CR) as well as the correllogram of squares residuals (CSR). In order to provide strong evidence on the reliability of the ARDL model, the study diagnosed the model for serial correlation, normality and heteroscedasticity.

In order to unveil the direction of causality, the study adopted a UVAR-based approach developed by Toda and Yamamoto (1995) to investigate the direction of causality between government spending and economic growth. This approach is called modified granger non-causality procedure.
Toda and Yamamoto (1995) developed a technique based on augmented UVAR system and a Wald test statistic which asymptotically has a chi square distribution. In this technique, the augmented UVAR system to be estimated has an order $\left(\mathrm{k}+\mathrm{d}_{\max }\right)^{\text {th }}$ where $\mathrm{k}$ is the optimal lag length of the system, $\mathrm{d}_{\max }$ is the maximum order of integration.

In line with Toda-Yamamoto procedure, the causality model for estimation would be in the form of a bivariate model with drift components and fixed exogenous variables.

The models to be estimated are therefore expressed as

$$
\begin{array}{r}
G D P_{t}=\alpha_{0}+\lambda_{i} X_{t}+\sum_{i=1}^{k} \phi_{1 i} G D P_{t-i}+\sum_{j=k+1}^{\mathrm{dmax}} \phi_{2 i} G D P_{t-j}+ \\
\sum_{i=1}^{k} \Omega_{1 i} G S_{t-i}+\sum_{j=k+1}^{\mathrm{dmax}} \Omega_{2 i} G S_{t-j}+\varepsilon_{1 t} \\
G S_{t}=\beta_{0}+\gamma_{i} X_{t}+\sum_{i=1}^{k} \psi_{1 i} G S_{t-i}+\sum_{j=k+1}^{\mathrm{dmax}} \psi_{2 i} G S_{t-j}+ \\
\sum_{i=1}^{k} \vartheta_{1 i} G D P_{t-i}+\sum_{j=k+1}^{\operatorname{dmax}} \vartheta_{2 i} G D P_{t-j}+\varepsilon_{2 t}
\end{array}
$$

From equation (25a), the null hypothesis tested is expressed as $\mathrm{H}_{0}: \Omega_{i}=0$, for all $i$. This implies government spending does not granger cause economic growth. The alternative hypothesis is expressed as $\mathrm{H}_{1}: \Omega_{i} \neq 0$, for all $i$ which implies government spending granger cause economic growth.

From equation (25b), the null hypothesis tested is expressed as $\mathrm{H}_{0}: \vartheta_{i}=0$, for all $i$. This implies government spending does not granger cause economic growth. The alternative hypothesis is expressed as $\mathrm{H}_{1}: \vartheta_{i} \neq 0$, for all $i$ which implies government spending granger cause economic growth.

\subsection{The Unit Root Models}

To identify the order of integration of each of the variables in the UVAR system, the study employed Augmented Dickey Fuller (ADF) and Philips-Peron (PP) unit root tests. The study specified Augmented Dickey-Fuller (ADF) unit root regression equation of the form

$$
\Delta Z_{t}=\eta_{0}+\eta_{1 t}+\eta_{2} Z_{t-1}+\sum_{j=1}^{p} \eta_{j} \Delta Z_{t-j}+e_{1 t}
$$

The equation regressed the first differences of the series on a constant, time trend, one lag of the series at level and lags of the series at first differences.

In order to apply Philips-Peron unit root test, the study followed a regression equation of the form

$$
\boldsymbol{K}_{\boldsymbol{t}}=\boldsymbol{\Psi}_{\mathbf{0}}+\boldsymbol{\mu}_{1 \boldsymbol{t}}+\boldsymbol{\rho} \boldsymbol{K}_{t-1}+\boldsymbol{\phi}\left[\boldsymbol{t}-\frac{T}{2}\right]+\sum_{j=1}^{m} \theta_{j} \Delta K_{t-j}+\boldsymbol{e}_{2 t}
$$

The regression equation (26) was implemented for this study because the PP test is said to be more robust to check against serial correlation. In both the equations (25) and (26), $\boldsymbol{\Delta}$ represents the first difference operator, $\boldsymbol{Z}_{\boldsymbol{t}}$ and $\boldsymbol{K}_{\boldsymbol{t}}$ are the time series under examination, $\boldsymbol{\eta}_{\mathbf{0}}, \boldsymbol{\Psi}_{\mathbf{0}}$ are constants terms, $\boldsymbol{e}_{1 t}$ and $\boldsymbol{e}_{2 t}$ are covariance stationary random error terms, $\mathrm{p}$ and $\mathbf{m}$ are the lag length to be used in the estimation. The lag length was chosen based on Schwarz Information Criterion (SC). The null hypothesis of unit root was tested using the tstatistic with critical values calculated by Mackinnon (1991). 
The null hypothesis of unit root is rejected in both equations (25) and (26) if $\boldsymbol{\eta}_{\mathbf{2}}$ and $\boldsymbol{\rho}$ are less than zero that is, if they are statistically significant.

\section{Empirical Results}

\subsection{Results of Unit Root Test}

The result of the unit root test is presented in Table 4. The result from the table shows that five of the variables used in this study are non-stationary since both the ADF and PP tests could not reject the hypothesis of a unit root at 5 percent level of significance. However these variables become stationary i.e. an $\mathrm{I}(0)$ process after differencing once indicating that they are integrated of order 1, that is, they follow a I(1) process. The five variables are per capita GDP (PCGDP), per capita government spending (PCGS), and domestic investment per capita (DOMINVPC), degree of trade openness (DTROPN) and financial market development (M2PCGDP). The result from both the ADF and PP tests are consistence on these five variables.

On the other hand, both tests provide a consistence result on inflation rate (ANNINFRT) as it is confirmed by both tests to be a $\mathrm{I}(0)$ process. The two tests confirmed that population growth rate (ANNPOPGRT) is $\mathrm{I}(0)$ for Senegal, Cote d'Ivoire and Ghana but I(1) in case of Burkina Faso and Nigeria. In case of Gambia, population growth rate is found to be $\mathrm{I}(0)$ based on ADF while PP test found it to be a $\mathrm{I}(1)$ process. It is important to mention here that, the growth rate of each of the two variables; GDP and government spending are found to be stationary in all the countries involved in this study and hence they enter our models where necessary as a $\mathrm{I}(0)$ process.

Table 4. Result of the Unit Root Test.

\begin{tabular}{|c|c|c|c|c|c|c|c|}
\hline \multirow[t]{2}{*}{ Country } & \multirow[t]{2}{*}{ Variable } & \multicolumn{2}{|c|}{$\begin{array}{l}\text { ADF Unit Root Test } \\
\text { Unit Root Statistic }\end{array}$} & \multirow{2}{*}{$\begin{array}{l}\text { Order of } \\
\text { Integration }\end{array}$} & \multicolumn{2}{|c|}{$\begin{array}{l}\text { PP Unit Root Test } \\
\text { Unit Root Statistic }\end{array}$} & \multirow{2}{*}{$\begin{array}{l}\text { Order of } \\
\text { Integration }\end{array}$} \\
\hline & & Level & First Difference & & Level & First Difference & \\
\hline \multirow{8}{*}{ Gambia } & LPCGDP & -1.416 & $-5.168^{*}$ & $\mathrm{I}(1)$ & -1.669 & $-5.176^{*}$ & $\mathrm{I}(1)$ \\
\hline & LPCGS & -2.615 & $-4.819 *$ & $\mathrm{I}(1)$ & -2.615 & $-5.248 *$ & $\mathrm{I}(1)$ \\
\hline & LDOMINVPC & -2.687 & $-5.020 *$ & $\mathrm{I}(1)$ & -2.750 & $-5.701 *$ & $\mathrm{I}(1)$ \\
\hline & GEFFCY & -2.715 & $-5.020 *$ & $\mathrm{I}(\mathrm{I})$ & -2.770 & $-6.310 *$ & $\mathrm{I}(1)$ \\
\hline & DTROPN & -1.631 & $-6.430^{*}$ & $\mathrm{I}(1)$ & -1.602 & $-6.430 *$ & $\mathrm{I}(1)$ \\
\hline & M2PCGDP & -0.842 & $-6.331 *$ & $\mathrm{I}(1)$ & -0.774 & $-6.331 *$ & $\mathrm{I}(1)$ \\
\hline & ANNINFRT & $-3.696 * *$ & - & $\mathrm{I}(0)$ & $-3.713 * *$ & - & $\mathrm{I}(0)$ \\
\hline & ANPOPGRT & $-6.499 *$ & - & $\mathrm{I}(0)$ & -0.389 & $-2.030 *$ & $\mathrm{I}(1)$ \\
\hline \multirow{8}{*}{ Senegal } & LPCGDP & -1.670 & $-4.800^{*}$ & $\mathrm{I}(1)$ & -1.830 & $-4.802 *$ & $\mathrm{I}(1)$ \\
\hline & LPCGS & -1.440 & $-4.318^{*}$ & $\mathrm{I}(1)$ & -1.626 & $-4.318 *$ & $\mathrm{I}(1)$ \\
\hline & LDOMINVPC & -2.624 & $-6.314^{*}$ & $\mathrm{I}(1)$ & -2.627 & $-7.424 *$ & $\mathrm{I}(1)$ \\
\hline & GEFFCY & -1.180 & $-5.789 *$ & $\mathrm{I}(1)$ & -1.293 & $-5.802 *$ & $\mathrm{I}(1)$ \\
\hline & DTROPN & -2.793 & $-5.757^{*}$ & $\mathrm{I}(1)$ & -2.725 & $-8.047 *$ & $\mathrm{I}(1)$ \\
\hline & M2PCGDP & -1.176 & $-5.933 *$ & $\mathrm{I}(1)$ & -1.066 & $-5.988 *$ & $\mathrm{I}(1)$ \\
\hline & ANNINFRT & $-4.274 *$ & - & $\mathrm{I}(0)$ & $-4.286^{*}$ & - & $\mathrm{I}(0)$ \\
\hline & ANPOPGRT & $-4.742 *$ & - & $\mathrm{I}(0)$ & $-3.796 * *$ & - & $\mathrm{I}(0)$ \\
\hline \multirow{8}{*}{ Cote d'Ivoire } & LPCGDP & -1.871 & $-5.280 *$ & $\mathrm{I}(1)$ & -1.941 & $-5.500 *$ & $\mathrm{I}(1)$ \\
\hline & LPCGS & -1.010 & $-4.720 *$ & $\mathrm{I}(1)$ & -1.234 & $-4.699 *$ & $\mathrm{I}(1)$ \\
\hline & LDOMINVPC & -2.687 & $-6.222 *$ & $\mathrm{I}(1)$ & -2.637 & $-7.219 *$ & $\mathrm{I}(1)$ \\
\hline & GEFFCY & -1.177 & $-4.262 * *$ & $\mathrm{I}(1)$ & -1.585 & $-4.257 * *$ & $\mathrm{I}(1)$ \\
\hline & DTROPN & -2.246 & $-5.091 *$ & $\mathrm{I}(1)$ & -2.242 & $-5.067 *$ & $\mathrm{I}(1)$ \\
\hline & M2PCGDP & -1.398 & $-6.914 *$ & $\mathrm{I}(1)$ & -1.398 & $-7.080 *$ & $\mathrm{I}(1)$ \\
\hline & ANNINFRT & $-4.274 *$ & - & $\mathrm{I}(0)$ & $-4.207 * *$ & - & $\mathrm{I}(0)$ \\
\hline & ANPOPGRT & $-4.875^{*}$ & - & $\mathrm{I}(0)$ & $-4.187 * *$ & - & $\mathrm{I}(0)$ \\
\hline \multirow{8}{*}{ Ghana } & LPCGDP & -0.835 & $-4.753 *$ & $\mathrm{I}(1)$ & -0.942 & $-4.716^{*}$ & $\mathrm{I}(1)$ \\
\hline & LPCGS & -1.608 & $-4.189 * *$ & $\mathrm{I}(1)$ & -1.405 & $-4.057 * *$ & $\mathrm{I}(1)$ \\
\hline & LDOMINVPC & -1.983 & $-5.435^{*}$ & $\mathrm{I}(1)$ & -2.086 & $-5.437 *$ & $\mathrm{I}(1)$ \\
\hline & GEFFCY & $-4.106^{* *}$ & - & $\mathrm{I}(0)$ & -2.602 & $-5.747 *$ & $\mathrm{I}(1)$ \\
\hline & DTROPN & -1.728 & $-5.098 *$ & $\mathrm{I}(1)$ & -1.812 & $-5.013 *$ & $\mathrm{I}(1$ \\
\hline & M2PCGDP & -2.500 & $-5.790 *$ & $\mathrm{I}(1)$ & -2.626 & $-5.791 *$ & $\mathrm{I}(1)$ \\
\hline & ANNINFRT & $-7.310^{*}$ & - & $\mathrm{I}(0)$ & $-10.482 *$ & - & $\mathrm{I}(0)$ \\
\hline & ANPOPGRT & $-7.375^{*}$ & - & $\mathrm{I}(0)$ & -2.389 & $-3.913 * *$ & $\mathrm{I}(1)$ \\
\hline \multirow{8}{*}{ Burkina Faso } & LPCGDP & -1.475 & $-5.000 *$ & $\mathrm{I}(1)$ & -1.556 & -4.996 & $\mathrm{I}(1)$ \\
\hline & LPCGS & -2.336 & $-5.303 *$ & $\mathrm{I}(1)$ & -2.443 & $-5.304 *$ & $\mathrm{I}(1)$ \\
\hline & LDOMINVPC & -1.886 & $-4.951 *$ & $\mathrm{I}(1)$ & -2.016 & $-5.042 *$ & $\mathrm{I}(1)$ \\
\hline & GEFFCY & $-5.105^{*}$ & - & $\mathrm{I}(0)$ & $-5.322 *$ & - & $\mathrm{I}(0)$ \\
\hline & DTROPN & -2.625 & $-5.250 *$ & $\mathrm{I}(1)$ & -2.637 & $-5.322 *$ & $\mathrm{I}(1)$ \\
\hline & M2PCGDP & -2.446 & $-6.420^{*}$ & $\mathrm{I}(1)$ & -2.485 & $-6.450 *$ & $\mathrm{I}(1)$ \\
\hline & ANNINFRT & $-4.717 *$ & - & $\mathrm{I}(0)$ & $-4.712 *$ & - & $\mathrm{I}(0)$ \\
\hline & ANPOPGRT & -2.522 & $-4.882 *$ & $\mathrm{I}(1)$ & -1.415 & $-3.863 * *$ & $\mathrm{I}(1)$ \\
\hline \multirow{3}{*}{ Nigeria } & LPCGDP & -2.164 & -6.735 & $\mathrm{I}(1)$ & -2.170 & -6.735 & $\mathrm{I}(1)$ \\
\hline & LPCGS & -2.570 & $-7.408^{*}$ & $\mathrm{I}(1)$ & -2.216 & $-7.407 *$ & $\mathrm{I}(1)$ \\
\hline & LDOMINVPC & -2.150 & $-4.816^{*}$ & $\mathrm{I}(1)$ & -2.263 & $-5.535^{*}$ & $\mathrm{I}(1)$ \\
\hline
\end{tabular}




\begin{tabular}{|c|c|c|c|c|c|c|c|}
\hline \multirow[t]{2}{*}{ Country } & \multirow[t]{2}{*}{ Variable } & \multicolumn{2}{|c|}{$\begin{array}{l}\text { ADF Unit Root Test } \\
\text { Unit Root Statistic }\end{array}$} & \multirow{2}{*}{$\begin{array}{l}\text { Order of } \\
\text { Integration }\end{array}$} & \multicolumn{2}{|c|}{$\begin{array}{l}\text { PP Unit Root Test } \\
\text { Unit Root Statistic }\end{array}$} & \multirow{2}{*}{$\begin{array}{l}\text { Order of } \\
\text { Integration }\end{array}$} \\
\hline & & Level & First Difference & & Level & First Difference & \\
\hline & GEFFCY & -2.371 & $-5.789 *$ & $\mathrm{I}(1)$ & -2.378 & $-5.789^{*}$ & $\mathrm{I}(1)$ \\
\hline & DTROPN & -1.088 & $-7.845^{*}$ & $\mathrm{I}(1)$ & -2.147 & $-7.840 *$ & $\mathrm{I}(1)$ \\
\hline & M2PCGDP & -3.208 & $-5.016^{*}$ & $\mathrm{I}(1)$ & -3.402 & $-5.016^{*}$ & $\mathrm{I}(1)$ \\
\hline & ANNINFRT & $-3.634 * *$ & - & $\mathrm{I}(0)$ & $-3.654 * *$ & - & $\mathrm{I}(0)$ \\
\hline & ANPOPGRT & -0.752 & $-8.857^{*}$ & $\mathrm{I}(1)$ & -1.936 & $-3.827 * *$ & $\mathrm{I}(1)$ \\
\hline \multicolumn{8}{|c|}{$\begin{array}{l}\text { * and } * * \text { denotes } 1 \% \text { and } 5 \% \text { significant levels respectively based on Mackinnon's Critical Values } \\
\text { Source: Author's Own Compilation }\end{array}$} \\
\hline
\end{tabular}

\subsection{The Result of the Johansen Multivariate Cointegration Test}

The study adopted the Johansen and Juselius multivariate cointegration technique to test for the cointegrating relationship among group of individually non-stationary variables. The Johansen procedure can detect the number of cointegrating vectors for any given group of individually non-stationary variables with equal order of integration. The Johansen test is based on maximal eigen value and the trace of the stochastic matrix. The result from both the trace statistic and maxima-eigen statistic as presented in Table 5 shows that cointegration exists among the variables in all the countries involved in the study. The two tests provide a consistent result on the cointegrating relationship among the variables concerned.

However, the number of cointegrating vectors varies across the countries. For instance, four cointegrating vectors were obtained for Gambia, two cointegrating vectors for each of Senegal, Ghana and Burkina Faso and three cointegrating vectors for each of Nigeria and Cote d'Ivoire. The presence of at least one cointegrating vector among the group of I(1) variables is an indication that a linear combination which is said to be stationary exists. The existence of cointegration allays the fear of spurious regression in the first instance since the variables on their own are non-stationary but there exists a linear combination of them that is stationary. The null hypothesis of no cointegration was rejected at 5 per cent level of significance as shown in the table.

The study also conducted a cointegration test within the UVAR system following a bivariate model in which GDP and government spending enters the system as endogenous. Other variables enter the UVAR system as exogenous. The result obtained is presented in Table 6 . The result from both the trace statistic and maxima-eigen statistic shows that cointegration exists between the two variables in all the countries involved in the study. The two tests provide a consistent result on the cointegrating relationship between the variables concerned. Except for Nigeria, two cointegrating vectors were found for each of the countries other than Nigeria. There is only one cointegrating vector in the case of Nigeria. This result shows that there exists a long run equilibrium relationship between government spending and economic growth in all the countries involved in the study.

Table 5. Result of Johansen and Juselius Multivariate Cointegration Test.

\begin{tabular}{|c|c|c|c|c|c|c|}
\hline Country & VAR(d) & Null Hypothesis & $\lambda \operatorname{Max}$ & $5 \%$ Critical Value & $\lambda$ Trace & $5 \%$ Critical Value \\
\hline \multirow{7}{*}{ Gambia } & \multirow{7}{*}{$\begin{array}{l}\text { VAR(1) based } \\
\text { on SIC }\end{array}$} & $\mathrm{r}=0$ & $85.80 *$ & 46.23 & $259.87^{*}$ & 125.62 \\
\hline & & $\mathrm{r} \leq 1$ & $72.09 *$ & 40.08 & $174.07 *$ & 95.75 \\
\hline & & $r \leq 2$ & $49.20 *$ & 33.88 & $101.98 *$ & 69.82 \\
\hline & & $r \leq 3$ & $28.90 *$ & 27.58 & $52.78 *$ & 47.86 \\
\hline & & $r \leq 4$ & 15.79 & 21.13 & 23.88 & 29.80 \\
\hline & & $\mathrm{r} \leq 5$ & 7.44 & 14.26 & 8.09 & 15.49 \\
\hline & & $r \leq 6$ & 0.65 & 3.84 & 0.65 & 3.84 \\
\hline \multirow{5}{*}{ Senegal } & \multirow{5}{*}{$\begin{array}{l}\text { VAR(1) based } \\
\text { on SIC }\end{array}$} & $\mathrm{r} \leq 1$ & $38.04 *$ & 33.88 & $85.00 *$ & 69.82 \\
\hline & & $r \leq 2$ & 22.82 & 27.58 & 46.96 & 47.86 \\
\hline & & $r \leq 3$ & 14.14 & 21.13 & 24.13 & 29.80 \\
\hline & & $r \leq 4$ & 8.13 & 14.26 & 9.99 & 15.49 \\
\hline & & $\mathrm{r} \leq 5$ & 1.86 & 3.84 & 1.86 & 3.84 \\
\hline \multirow{6}{*}{ Ghana } & \multirow{6}{*}{$\begin{array}{l}\text { VAR(1) based } \\
\text { on SIC }\end{array}$} & $r=0$ & $106.62 *$ & 46.23 & $228.92 *$ & 125.62 \\
\hline & & $r \leq 1$ & $60.33^{*}$ & 40.08 & $122.29 *$ & 95.75 \\
\hline & & $\mathrm{r} \leq 3$ & 22.88 & 27.58 & 36.89 & 47.86 \\
\hline & & $r \leq 4$ & 7.04 & 21.13 & 14.02 & 29.80 \\
\hline & & $\mathrm{r} \leq 5$ & 5.88 & 14.26 & 6.98 & 15.49 \\
\hline & & $r \leq 6$ & 1.09 & 3.84 & 1.09 & 3.84 \\
\hline \multirow{6}{*}{ Cote d'Ivoire } & \multirow{6}{*}{$\begin{array}{l}\text { VAR(1) based } \\
\text { on SIC }\end{array}$} & $r=0$ & $97.72 *$ & 40.08 & $196.62 *$ & 95.75 \\
\hline & & $\mathrm{r} \leq 1$ & $46.20 *$ & 33.88 & $98.90 *$ & 69.82 \\
\hline & & $r \leq 2$ & $32.80 *$ & 27.58 & $52.70 *$ & 47.86 \\
\hline & & $r \leq 3$ & 13.39 & 21.13 & 19.90 & 29.80 \\
\hline & & $r \leq 4$ & 6.41 & 14.26 & 6.51 & 15.49 \\
\hline & & $r \leq 5$ & 0.10 & 3.84 & 0.10 & 3.84 \\
\hline Burkina Faso & VAR(2) based & $\mathrm{r}=0$ & $55.67 *$ & 40.08 & $133.17 *$ & 95.75 \\
\hline
\end{tabular}




\begin{tabular}{|c|c|c|c|c|c|c|}
\hline Country & $\operatorname{VAR}(d)$ & Null Hypothesis & $\lambda \operatorname{Max}$ & $5 \%$ Critical Value & $\lambda$ Trace & $5 \%$ Critical Value \\
\hline \multirow{12}{*}{ Nigeria } & \multirow{5}{*}{ on AIC } & $\mathrm{r} \leq 1$ & $34.59 *$ & 33.88 & $77.50 *$ & 69.82 \\
\hline & & $r \leq 2$ & 23.23 & 27.58 & 42.91 & 47.86 \\
\hline & & $r \leq 3$ & 13.32 & 21.13 & 19.68 & 29.80 \\
\hline & & $r \leq 4$ & 4.51 & 14.26 & 6.36 & 15.49 \\
\hline & & $\mathrm{r} \leq 5$ & 1.85 & 3.84 & 1.85 & 3.84 \\
\hline & \multirow{7}{*}{$\begin{array}{l}\text { VAR(1) based } \\
\text { on SIC. }\end{array}$} & $\mathrm{r}=0$ & $111.41^{*}$ & 46.23 & $249.84 *$ & 125.61 \\
\hline & & $\mathrm{r} \leq 1$ & $54.41 *$ & 40.08 & $138.42 *$ & 95.75 \\
\hline & & $\mathrm{r} \leq 2$ & $33.91 *$ & 33.88 & $84.02 *$ & 69.82 \\
\hline & & $\mathrm{r} \leq 3$ & 24.29 & 27.58 & 50.11 & 47.86 \\
\hline & & $\mathrm{r} \leq 4$ & 15.70 & 21.13 & 25.81 & 29.80 \\
\hline & & $\mathrm{r} \leq 5$ & 8.81 & 14.26 & 10.11 & 15.49 \\
\hline & & $\mathrm{r} \leq 6$ & 1.31 & 3.84 & 1.31 & 3.84 \\
\hline
\end{tabular}

Source: Author's Own Compilation

Table 6. Result of Bivariate Cointegration Test.

\begin{tabular}{|c|c|c|c|c|c|c|}
\hline Country & VAR(d) & Null Hypothesis & $\lambda \operatorname{Max}$ & $5 \%$ Critical Value & $\lambda$ Trace & 5\% Critical Value \\
\hline \multirow{2}{*}{ Gambia } & \multirow{2}{*}{ VAR(4) based on SIC. } & $\mathrm{r}=0$ & 40.066 & 14.265 & 44.059 & 15.495 \\
\hline & & $r \leq 1$ & 3.994 & 3.841 & 3.994 & 3.841 \\
\hline \multirow{2}{*}{ Senegal } & \multirow{2}{*}{ VAR(1) based on SIC. } & $\mathrm{r}=0$ & 160.109 & 14.265 & 187.117 & 15.495 \\
\hline & & $\mathrm{r} \leq 1$ & 27.007 & 3.841 & 27.007 & 3.841 \\
\hline \multirow{2}{*}{ Ghana } & \multirow{2}{*}{ VAR(1) based on SIC. } & $\mathrm{r}=0$ & 102.328 & 15.495 & 79.775 & 14.265 \\
\hline & & $\mathrm{r} \leq 1$ & 22.551 & 3.841 & 22.553 & 3.841 \\
\hline \multirow{2}{*}{ Cote d'Ivoire } & \multirow{2}{*}{ VAR(2) based on SIC. } & $\mathrm{r}=0$ & 98.278 & 14.265 & 126.708 & 15.495 \\
\hline & & $r \leq 1$ & 28.430 & 3.841 & 28.430 & 3.841 \\
\hline \multirow{2}{*}{ Burkina Faso } & \multirow{2}{*}{ VAR(2) based on AIC. } & $\mathrm{r}=0$ & 159.194 & 14.265 & 188.238 & 15.495 \\
\hline & & $r \leq 1$ & 29.044 & 3.841 & 29.044 & 3.841 \\
\hline \multirow{2}{*}{ Nigeria } & \multirow{2}{*}{ VAR(1) based on SIC. } & $\mathrm{r}=0$ & 100.539 & 14.265 & 101.063 & 15.495 \\
\hline & & $\mathrm{r} \leq 1$ & 0.524 & 3.841 & 0.524 & 3.841 \\
\hline
\end{tabular}

Source: Author's Own Compilation

\subsection{The ARDL Bound Test Results}

The results of the ARDL-Bound test as presented in Table 7 provide further information on the long run equilibrium relationship between government spending and economic growth in the selected countries. The null hypothesis of no long run relationship between government spending and economic growth was tested and the results are reported in the table. The computed F-statistic is greater than the upper bound at 10 per cent, 5 percent and even at 1 percent significance levels for all the six countries. This implies the existence of long run equilibrium relationship between government spending and economic growth in these countries. This result is consistent with what we obtained in the previous analysis.

The ARDL model for each country was properly diagnosed for serial correlation using the correllogram of residuals with reported Q-statistic and the corresponding $\mathrm{p}$ value for each country and the hypothesis of no serial correlation in the residuals cannot be rejected for each country. This shows the absence of serial correlation. The LM-test is also used to test for serial correlation in the residuals and the null hypothesis of no serial correlation cannot be rejected in all the cases showing the absence of serial correlation We equally diagnosed the ARDL model for each country for normality in the behavior of the residuals by using the JB-statistic with its corresponding p-value for each country. The hypothesis of normality in the residuals cannot be rejected for each country and hence it is concluded that there is normality in the behavior of the residuals. We equally diagnosed the residuals of the ARDL model for heteroscedasticity and the hypothesis of homoscedasticity in the residuals cannot be rejected. This shows that the residuals in the ARDL models are homoscedastic. The R-square and adjusted R-square for each model suggests that the model is of good fit.

Table 7. Result of the ARDL Bound Tests for Long run Relationship.

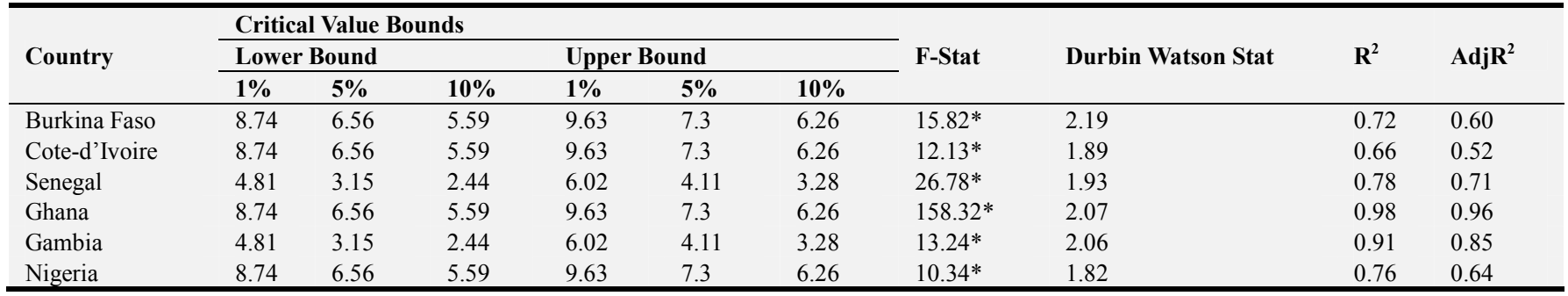

Source: Author's Own Compilation 


\subsection{The Short Run Dynamic Between Government Spending and Economic Growth}

The results of the error correction models are presented in Table 8. From the result reported, the short run behavior of government spending and economic growth is revealed. The coefficient of the error correction term in the modified ARDL model for each country is significant and negatively signed in line with a priori expectation. This implies that variables return to their long run equilibrium path after a short run deviation from equilibrium. The results also indicate that the speed of adjustment varies across the countries concerned. For instance, about 69 percent of disequilibria in the previous year are corrected for in the current year in the case of Nigeria. This further implies that in the case of Nigeria, the equilibrium would be restored in less than two years.

In the case of Burkina Faso, about 51 percent of disequilibria are corrected for in the current year. Also, it would take almost two years to restore equilibrium in the case of Burkina Faso. In the case of Cote d'Ivoire, about 42 percent of disequilibria are corrected for in the current year. By this result, it would take about two and half years to restore equilibrium in Cote d'Ivoire. In the case of Ghana, about 36 percent of disequilibria are corrected for in the current year. This result also indicates that it would take Ghana about three years to restore equilibrium. In the case of Senegal, about 17 percent of disequilibria are corrected for in the current year. The implication of this is that, it would take about six years to restore equilibrium in Senegal. In the case of Gambia, about 16 percent of disequilibria are corrected for in Gambia. This also implies that it would take about six years three months to restore equilibrium in Gambia.

With this result, it evidenced that the short run behavior of government spending and economic growth varies across the six countries. This implies that fiscal harmonization in these countries might not be easy because they exhibit different short run behavior. To bring them together under a unified fiscal regime might take some time.

Table 8. Result of the Error Correction Model - the Modified ARDL Model.

\begin{tabular}{|c|c|c|c|c|c|c|}
\hline Statistic/Country & Burkina Faso & Cote d'Ivoire & Senegal & Ghana & Gambia & Nigeria \\
\hline $\operatorname{ECM}(-1)$ & -0.507 & -0.416 & -0.169 & -0.356 & -0.159 & -0.686 \\
\hline T-ratio & -4.366 & -2.782 & -3.603 & -9.566 & -4.85 & -4.094 \\
\hline P-value & 0.002 & 0.010 & 0.002 & 0.000 & 0.010 & 0.001 \\
\hline
\end{tabular}

Source: Author's Own Compilation

\subsection{Direction of Causality Between Government Spending and Economic Growth}

This study employed the UVAR-based Toda and Yamamoto Modified Granger non- causality to entangle the direction of causality between government spending and economic growth. The first stage in the procedure of Toda and Yamamoto is to find out the maximum order of integration of the variables involved and this is denoted by $\left(\boldsymbol{d}_{\max }\right)$. To do this, we fall back to the result of the unit root test where it is revealed that the maximum order of integration is 1 for all the countries. The next stage is to determine the optimal lag length denoted by (k). This is done by using Swartz Information Criteria (SIC). In the case of Ghana, Nigeria and Senegal, $\mathrm{k}=1$ while in the case of Burkina Faso, Cote d'Ivoire and Gambia, $\mathrm{k}=6, \mathrm{k}=3$ and $\mathrm{k}=4$ respectively. The SIC is more robust in selecting the most parsimonious model.

The result of the estimated model is presented in Table 9. From this result, it is evidenced that bidirectional causality relation exists between government spending and economic growth in Gambia, Senegal, Cote d'Ivoire and Burkina Faso. This provides empirical evidence that causality runs in both direction that is it runs from economic growth to government spending and vice versa lending support to or upholding the feedback hypothesis in these countries. The finding here corroborates with those of Yaya (2015) for Burkina Faso. There is no evidence in support of feedback hypothesis in the case of Nigeria and Ghana where a unidirectional causality running from economic growth to government spending is obtained. This validates the Wagnerian hypothesis otherwise known as growth-spent hypothesis in these countries. This finding also corroborates with those of Yaya (2015) for Ghana and Nigeria, Olomola (2004) and Akinlo (2013) for Nigeria but in conflict with Omoke (2009), Chimobi (2009), Sevtenyi (2012), Muse, et al.(2013) for the Nigerian economy, Gadinabokao and David (2013) for the developing economy of South Africa and Yaya (2015) for Gabon and Senegal.

Table 9. Result of the UVAR-based Toda and Yamamoto Modified Granger Non-causality Models.

\begin{tabular}{|c|c|c|c|c|}
\hline \multirow[t]{2}{*}{ Country } & \multicolumn{2}{|c|}{$\begin{array}{l}\text { Causality Direction Running From GDP to Government } \\
\text { Spending }\end{array}$} & \multicolumn{2}{|c|}{$\begin{array}{l}\text { Causality Direction Running From Government Spending to } \\
\text { GDP }\end{array}$} \\
\hline & $\chi^{2}-$ Statistic & P-value & $\chi^{2}$ - Statistic & P-value \\
\hline Gambia & $23.628 *$ & 0.0003 & $12.812^{* *}$ & 0.025 \\
\hline Ghana & $7.248 * *$ & 0.027 & 4.297 & 0.117 \\
\hline Cote d'Ivoire & $9.902 * *$ & 0.020 & $10.277 * *$ & 0.016 \\
\hline Burkina Faso & $24.319 *$ & 0.000 & $26.574 *$ & 0.000 \\
\hline Nigeria & $18.235^{*}$ & 0.000 & 0.172 & 0.918 \\
\hline
\end{tabular}

Source: Author's Own Compilation 


\section{Conclusions}

In conclusion, government spending is very important for economic growth in the ECOWAS sub-region. To raise income per capita in the region, efficiency is a necessary and not a sufficient condition. Government spending should be jerked up sufficiently to boost aggregate demand such that raises the production capacity of the economy. While focusing on efficiency variable, government spending should be raised to the appreciable level to make a meaningful and significant impact on the economy. This implies that fiscal consolidation campaign as put forward by IMF (2003) should be taken with caution as this might hamper economic growth in this region considering the prevailing conditions in term of low level of infrastructure as well as low income per capita in this economic sub-region. The alternative policy recommendation is the campaign for fiscal space with strong consideration to efficiency variable which may be a better option to advance the developing economy of West African Countries. As government spending increases, greater proportion should be devoted to the provision of road, electricity, pipe-borne water, education, health, telecommunication, defence and social security and agriculture. These components are said to be growth enhancing. They constitute the infrastructural-base for the socio-economic development in the modern society. It is however important to note that the desire to industrialize, continuous increase in population, more desire for civilization and modernization could aggravate the growth of government spending if such trend continues. This is in line with the Wagnerian thesis. Based on the findings of this study, there is strong empirical evidence in support of long run equilibrium, short run dynamic and causality relations between government spending and economic growth.

The study therefore concluded that fiscal neutrality hypothesis is baseless since government spending among other variables, have a clear cut link with economic growth in the developing economies of West Africa in the ECOWAS sub-region.

\section{References}

[1] Abdullah, H. A. (2000). The Relationship between Government size and Economic Growth in Saudi Arabia. Journal of Administrative Science, 12(2): 173-191.

[2] Abizadeh, S. and Gray, J. (1985). "Wagner's Law: A Pooled Time-Series Cross-Section Comparison," National Tax Journal, 88, 209-218.

[3] Abu, N. and Abdullahi, U. (2010). Government Expenditure and Economic Growth in Nigeria, 1970-2008: A Disaggregated Analysis. Business and Economics Journal.

[4] Adam, C. and Bevan, D. (2005). Fiscal deficits and growth in developing countries. Journal of Public Economics, vol. 89, no. 4 , pp. 571-597.

[5] Adeoye, T. (2006). Fiscal Policy and Growth of the Nigerian
Economy: An Empirical Perspective. Ibadan: NISER monograph series No. 3 .

[6] Afxentiou, P. C., and Serletis, A. (1996). "Government Expenditures in the European Union: Do They Converge or Follow Wagner's Law?" International Economic Journal, 10, 33-47.

[7] Agiobenebo, T. J. and Onuchukwu, O. (2000). "An Econometric Study of Public Investment Behavior in Nigeria (1970-1996)". Social science study group monograph series No. 5 Port Harcourt: Emhai Printing and Publishing Company.

[8] Aigbokhan, B. E. (1996). "Government Size and Economic Growth: The Nigerian Experience", in "Beyond Adjustment: Management of the Nigerian Economy". Proceedings of the 1996 annual Conference of the Nigerian Economic Society.

[9] Akinlo, A. E. (2013). "Government Spending and National Income Nexus for Nigeria”, Global Journal of Business Research, 7(1) pp. 33-41.

[10] Akpan, N. I. (2005). Government Expenditure and Economic Growth in Nigeria: A Disaggregated Approach. CBN Economic and Financial Review. 43(1).

[11] Alfaris, A. F. (2002). Public Expenditure and Economic Growth in the Gulf Cooperation Council Countries. Applied Economics, 34, 1187-1193.

[12] Al-Yousif, Y. (2000). Does Government Expenditure Inhibit or Promote Economic Growth: Some Empirical Evidence from Saudi Arabia. Indian Economic Journal, 48(2).

[13] Ansari, M. I., Gordon, D. V., and Akuamoach, C. (1997). "Keynes versus Wagner: Public Expenditure and National Income for Three African Countries," Applied Economics, 29, 543-550.

[14] Aregbeyen, O. (2006). "Cointegration, Causality and Wagner's Law: A Test for Nigeria, 1970-2003”. Central Bank of Nigeria Economic and Financial Review, 44 (2).

[15] Aschauer, D. A., (2000). "Public Capital and Economic Growth: Issues of Quantity Finance, and Efficiency," Economic Development and Cultural Change, 48(2). 391-406.

[16] Babatunde, M. A. and Adefabi, R. A. (2005). Long Run Relationship between Education and Economic Growth in Nigeria: Evidence from the Johansen's Cointegration Approach. Paper presented at the Regional Conference on Education in West Africa: Constraints and Opportunities Dakar, Senegal, November $1^{\text {st }}$-2nd. Cornell University/CREA/Ministèrede l'Education du Senegal.

[17] Babatunde, M. A. (2007). A bound testing analysis of Wagner's law in Nigeria: 1970-2006. Proceedings of Africa Metrics Conference; http://www.africametrics.org/

[18] Bakare, A. S. and Olubokun S. (2011). Health Care Expenditure and Economic Growth in Nigeria: An Empirical study. Journal of Emerging Trends in Economics and Mnagement Sciences (JETEMS) 2(2): 83-87 Copy right Scholarlink Research Institute Journals, 2011(ISSN; 21417024) jetems.scholarlinkresearch.org.

[19] Barro, R. and Sala-i-Martin, X. (1992). Public Finance in Models of Economic Growth. Review of Economic Studies, 59: 645-661. 
[20] Barro, R. (1990). Government Spending in a Simple Model of Endogenous Growth. Journal of Political Economy, 98(5):103-125.

[21] Barro, R. (1991). Economic Growth in Cross-Section of Countries. Quarterly Journal of Economics, 106(2): 407-443. Bhatia, H. L. (1982). Public Finance. New Delhi: Vikas publishing.

[22] Biswal, B., Dhawan U. and Lee H. Y. (1999). Testing Wagner Versus Keynes using disaggregated public expenditure data for Canada. Applied Economics, 31. 1283- 1291.

[23] Blejer, M. I. and Khan, M. S. (1984). "Government policy and private investment in developing countries". IMF Staff Papers, 31(2): 379-403.

[24] Bose, N., Hague, M. E. and Osborn, D. R. (2007). Public Expenditure and Economic Growth; A Disaggregated Analysis for Developing Countries. The Machester School, 75-85, 533556. Boston: McGraw Hill Inc.

[25] Brennan, G. and Buchanan, J. (1980). "The power to tax: Analytical foundations of a fiscal Constitution". Cambridge: Cambridge University Press.

[26] Brons, M, Groot, H. and Nijkamp P, (1999). Growth Effects of Fiscal Policies. Tinbergen Discussion Paper, Amsterdam: Vrije Universiteit.

[27] Buchanan, J. M., Wagner, R. W. (1978). Dialogues concerning fiscal religion. Journal of Monetary Economics, 4: 627-636.

[28] Buiter, W. H. (1988). Can Public Spending Cuts Be Inflationary? NBER Working Paper, 2528, March.

[29] Burney, N. A. (2002). "Wagner's Hypothesis: Evidence from Kuwait Using Cointegration tests". Applied Economics (34), 49-57.

[30] Chang, T. (2002), “An Econometric Test of Wagner's Law for Six Countries, based on Cointegration and Error-Correction Modelling Techniques," Applied Economics. 34, 1157-1169.

[31] Cass, D. (1965). "Optimum Growth in an Aggregative Model of Capital Accumulation." Review of Economic Studies. 32: 233-40.

[32] Chimobi, O. P. (2009). Government Expenditure and National Income: A Causality Test for Nigeria, European Journal of Economic and Political Studies. 2: 1-11.

[33] Chinedu, B. E., Mike, I. M. and Uchenna, E. (2008). "Inflation Versus Public Expenditure Growth In The Us: An Empirical Investigation". North American Journal of Finance and Banking Research. 2(2): 26-40.

[34] Clark, C. (1945). Public Finances and Changes in the Value of Money, Economic Journal, December, 371-389.

[35] Cooray, A. (2009). Government Expenditure, Governance and Economic Growth. Comparative Economic Studies, 51(3): 401-418.

[36] David Hauner and Annette Kyobe (2008)." Determinants of Government Efficiency”. IMF Working Paper, WP/08/228.

[37] Devarajan, S. Swaroop V. and Zou H. (1996). The Composition of Public Expenditure and Economic Growth. Journal of Monetary Economics, 37: 313-344.

[38] Dogan, E. and Tang, T. C. (2006). Government Expenditure and National Income: causalityTest For Five South East Asian Countries, International Business \& Economics Research
Journal, 5(10): 49-58.

[39] Easterly, W. and Rebelo S. (1993). Fiscal Policy and Economic Growth: An Empirical Investigation. Journal of Monetary Economics, 32: 417-458.

[40] Ekpo, A. (1994). Public Expenditure and Economic Growth in Nigeria; 1960-1992. Final Report. AERC, Nairobi.

[41] Enang, B. Udah (2010). Macroeconomic Reforms, Government Size, And Investment Behavior In Nigeria: An Empirical Investigation. Journal of Sustainable Development in Africa 12(1). Clarion University of Pennsylvania, Clarion, Pennsylvania. ISSN: 1520-5509.

[42] Engle, R. F. Granger, CWJ. (1987). Cointegration and error correction: Representation, estimation and testing. Econometrica. 55: 251-276.

[43] Erkin, B. (1988). Government Expenditure and Economic Growth: Reflections on Professor Ram's Approach, A New Framework and Some Evidence from New Zealand Time Series Data. Keio Economic Studies, 25(1): 59-66.

[44] Ezirim, B. C. and Muoghalu, M. I. (2006). "Explaining the Size of Public Expenditure in Less Developed countries. Theory and Empirical Evidence from Nigeria. ABSU Journal of Management Sciences, 2(2): 134-154.

[45] Ezirim, B. C. and Ofurum, C. O. (2003). "Public Expenditure Growth and Inflation in Developed and Less Developed Countries" Nigerian Business and Social Review, 2(1): 75-94.

[46] Ezirim, B. C., Muoghalu, M. I. and Elike, U. (2008). Inflation versus Public Expenditure Growth in the US: an Empirical Investigation, North American. Journal of Finance and Banking Research, 2(2): 26-40.

[47] Fajingbesi, A. A. and Odusola, A. F. (1999). Public Expenditure and Growth. A Paper Presented at a Training Programme on Fiscal Policy Planning Management in Nigeria, Organized by NCEMA, Ibadan, Oyo State, 137-179.

[48] Fedderke, J., Perkins, P. and Luiz, J. (2006). Infrastructural investment in long run economic growth: South Africa 18752001, World Development, 34(6): 1037-1059.

[49] Fluente, A. (1997). Fiscal Policy and Growth in the OECD. Discussion Paper Series No. 1755. Center for Economic Policy Research: London UK.

[50] Folorunso, B. A. and Olayeni, O. R. (2006). Public Expenditure and Economic Growth: Causal Evidence from Nigeria. Ife Social Sciences Review 20(1).

[51] Gabriel C., Hlanganipai N., Mangena M. and Yewukai R. (2014). "The Impact of Government Spending on Economic Growth: Case of South Africa". Mediterranean Journal of Social Sciences, MCSER Publishing, Rome-Italy. Vol 5 No 1. Pp 109-118.

[52] Granger, CWJ. and Newbold, P. (1974). Spurious Regression in Econometrics. Journal of Economics. 2: 111-20.

[53] Granger, CWJ. (1969). Investigating Causal Relations by Econometric Models and Cross-Spectral Methods, Econometrica, 37, 424-438.

[54] Gregoriou, A. and Ghosh, S. (2007). The Impact of Government Expenditure on Growth: Empirical Evidence from Heterogeneous Panel. [http://www.brunel.ac.uk/9379/efwps /0701.pdf] 
[55] Gupta, S. P. (1967). Public Expenditure and Economic Growth: A Time Series Analysis. Public Finance, 22: 423-61.

[56] Haque, M. (2004). The Composition of Public Expenditure and Economic Growth in Developing Countries,. Global. Journal of Finance and Economics, 1(1): 97-117.

[57] Haque, M. and Kim, D. (2003). Public investment in transportation and communication and growth: A dynamic panel approach,. Centre for Growth and Business Cycle Research, Economic Studies, University of Manchester, Discussion Paper Series, No. 031.

[58] Huang, C. J. (2006). "Government Expenditures In China And Taiwan: Do They Follow Wagner's Law?" Journal of Economic Development, 31(2): 139-148.

[59] Johansen, S. and Juselius, K. (1990). Maximum Likelihood Estimation and Inference on Cointegration with Applications to the Demand for Money, Oxford Bulletin of Economics and Statistics, 52, 169-210.

[60] Kabeya, C. M. (2009). Long-run Relationship Between Government Expenditure and Economic Growth: Evidence from SADC Countries. Unpublished Master Thesis, University of Johannesburg, South Africa.

[61] Kneller, R, Bleaney, M. and Gemmell, N. (1999). Fiscal Policy and Growth: Evidence from OECD Countries. Journal of Public Economics, 74: 171-190.

[62] Kolluri, B. R., Panic, J. M., and Wahab, M. (2000). Government Expenditure and Economic Growth; Evidence from G7 Countries. Applied Economics, 32: 1059-1068.

[63] Komain, J. and Brahmasrene, T, (2007). The Relationship between Government Expenditures and Economic Growth in Thailand. Journal of Economics \& Economic Education Research.

[http://findarticles.com/p/articles/mi_qa5529/?taqcontent;co11]

[64] Lamartina, S. and Zaghini, A. (2008). Increasing Public Expenditures: Wagner's Law in OECD Countries, Center for Financial Studies Working Papers, 13.

[65] Laudau, D. (1983). Government Expenditure and Economic Growth: A Cross Country Study. Southern Economic Journal, 49: 783-792.

[66] Lin, C. A. (1995). "More Evidence on Wagner's Law for Mexico," Public Finance, 50, 262-277.

[67] Liu, C., Hsu, C. and Younis, M. Z. (2008). The Association between Government Expenditure and Economic Growth: The Granger Causality Test of the US Data, 1974-2002. Journal of Public Budgeting, Accounting and Financial Management, 20(4): 439-52.

[68] Loizides, J. and Vamvoukas, G. (2005). Government Expenditure and Economic Growth: Evidence from Trivariate Causality Testing. Journal of Applied Economics, 8(1): 125152.

[69] Lopez, R. and Miller, S. (2007). The Structure of Public Expenditure: A Robust Predictor of Economic Development? Unpublished manuscript.

[70] MacKinnon, J. G. (2010). "Critical Values for Cointegration Tests," Working Papers 1227, Queen's University, Department of Economics.

[71] Magazzino, C. (2010). "Wagner's Law" in Italy: Empirical
Evidence from 1960 to 2008, Global \& Local Economic Review, 2: 91-116.

[72] Magazzino, C., (2011). Wagner's Law and Italian disaggregated public spending. Some empirical evidences. Journal of Policy Modelling, forthcoming.

[73] Maku, O. E. (2009). "Does Government Spending Spur Economic Growth in Nigeria?" MPRA Paper No.17941. http://mpra.ub.uni-muenchen.de/1794/

[74] Marlow, M. L. and Manage, N. (1987). Expenditures and receipts: Testing for causality in state and local government finances. Public Choice, 53(3): 243-255.

[75] Meltzer, A. and Richard, S. (1981). A Rational Theory of the Size of Government, Journal of Political Economy 89, 914927. Michas, N. A., (1975). Wagner's law of Public Expenditure: What Appropriate Measurement for a valid Test? Public Finance, 30, 77-84.

[76] Milbourne, R., Otto, G. and Voss, G. (2003). Public investment and economic growth. Applied Economics, 35(5): 527.540

[77] Mitchell, J. D. (2005). The Impact of Government Spending on Economic Growth, Backgrounder, 1831. [www.heritage.org/research/budget/bg1831.cfm]

[78] Narayan, P. K., Nielsen, I. and Smyth, R. (2008). Panel Data, Cointegration, Causality and Wagner's law: Empirical from Chinese Provinces. China Economic Review, 19: 297-307.

[79] Nijkamp, P. and Poot, J. (2004). Meta-analysis of the Effect of Fiscal Policy on Long run Growth. European Journal of Political Economy, 20: 91-124.

[80] Olomola, P. A (2004). "Cointegration Analysis-causality Testing and Wagner's Law: The Case of Nigeria (19702001)", Journal of Social and Economic Development, vol. 6, pp. 76-90.

[81] Olugbenga, A. O. and Owoye, O. (2007). Public Expenditure and Economic Growth: New Evidence from OECD Countries. [http://iaes.confex.com/iaes/Rome_67/techprogram/]

[82] Oxley, L. (1994). Cointegration, Causality and Wagner's Law: A Test for Britain 1870-1913, Scottish Journal of Political Economy, 41: 286-298.

[83] Oyinlola, O. (1993). Nigeria's National Defence and Economic Development: An Impact Analysis. Scandinavian Journal of Development Alternatives, 12(3): 123-142.

[84] Peacock, A. and Wiseman, J. (1979). Approaches to the analysis of government expenditure growth. Public Finance Review, 7: 3-23.

[85] Peacock, A. T. and Wiseman, J. (1961). The Growth of Public Expenditure in the United Kingdom. Princeton N. J: Princeton University Press for the National Bureau of Economic Research.

[86] Pekarski, S. (2010). Budget deficits and inflation feedback, Structural Change and Economic Dynamics. 22(1): 1-11.

[87] Pesaran, H. M., Shin, Y., \& Smith, R. J. (2001). Bounds testing approaches to the analysis of long-run relationships (Working paper no. 9907). Cambridge, United Kingdom: Department of Applied Economics, University of Cambridge. 
[88] Peter, S. (2003). Government Expenditures Effect on Economic Growth: The Case of Sweden, 1960-2001. A Bachelor Thesis Submitted to the Department of Business Administration and Social Sciences, Lulea University of Technology, Sweden.

[89] Phillips, P. and Ouliaris, S. (1990). Asymptotic Properties of residual based test for cointegration, Econometrica 58: 73-93.

[90] Ram, R. (1986). Government Size and Economic Growth: A New Framework and Some Evidence from Cross-Section and Time-Series Data. American Economic Review, 76: 191-203.

[91] Ramirez, M. and Nazmi, N. (2003). Public investment and economic growth in Latin America: An empirical test, Review of Development Economics, 7(1): 115-126.

[92] Ranjan, K. D. and Sharma C, (2008). Government Expenditure and Economic Growth: Evidence from India. The ICFAI University Journal of Public Finance, 6(3): 60-69.

[93] Romer, P. M. (1990). "Endogenous Technological Change." Journal of Political Economy, 98(5): 71-102.

[94] Rostow, W. W. (1971). Politics and the Stages of Growth, Cambridge: Cambridge University Press.

[95] Schalteger, C. A. and Torgler, B. (2006). Growth Effects of Public Expenditure on the state and local level: Evidence from a sample of rich government. Applied Economics, 38, 11811192.

[96] Singh, B. and Sahni, B. S. (1984). Causality between Public Expenditure and National Income. The Review of Economics and Statistics, 66, 630-44.

[97] Sevitenyi, I. N. (2012), Government Expenditure and Economic Growth in Nigeria: An Empirical Investigation (1961-2009). The Journal of Economic Analysis, 3(1), pp3851.

[98] Scrinivasan, P. (2013), Causality between Public Expenditure and Economic Growth: The Indian Case. International Journal of Economics and Management, 7(2), pp 335-347.

[99] Solow, R. M. (1956). "A Contribution to the Theory of Economic Growth.” Quarterly Journal of Economics, 70(1): 65-94.
[100] Soludo, C. C. (2015). "Buhari Versus Jonathan: Beyond the Election.” Daily Sun, 10(3065), Jan. 27, Tue pp.64.

[101] Stephen K. P, Josh D. S and Pedro V. P (2011). "What Does the Penn Word Table 7.0 Tell us about Government Expenditure and Economic Growth?" Iinternational Journal of Economics and Management Sciences, 1, 4, 98-111.

[102] Tulsidharan, S. (2006). Government Expenditure and Economic Growth in India (1960-2000). Finance India, 20, 1, 169-179.

[103] Turnovsky, S. (2004). The Transitional Dynamics of Fiscal Policy: Long-Run Capital Accumulation and Growth. Journal of Money, Credit, and Banking, 36(5).

[104] Uzawa, H. (1965). Optimal Technical change in an Aggregate Model of Economic Growth. International Economic Review, 6, pp. 18-31.

[105] Varvarigos, D. (2010). Inflation, volatile public spending, and endogenously sustained growth, Journal of Economic Dynamics \& Control, 34: 1893-1906.

[106] Wagner, A. (1890). Classic in the Theory of Public Finance. London, and Macrnillan. $3^{\text {rd }}$ ed. (Leipzigt partly reprinted in R. A. Musgrave and A. T. Peacock (1958).

[107] Wagner, R. E. and Weber, W. E. (1977). "Wagner's Law, Fiscal Institutions and the Growth of Government," National Tax Journal, 30: 59-68.

[108] Wahab, M. (2004). Economic Growth and Government Expenditure. Evidence from a new Test Specification. Applied Economics, 36: 2125-2135.

[109] Wahab, A. L and Rihanat, I. A (2011). "An Analysis of Government Spending on Educational Sector and its Contribution to GDP in Nigeria". International Journal of Financial Economics and Econometrics, 3(1): 163-170.

[110] Weil, David N. (2009). Economic Growth 2nd edition. Prentice Hall.

[111] Wu S-Y. Tang J-H. and Lin E. (2010) "The Impact of Government Expenditure on Economic Growth: How Sensitive to the Level of Investment?" Journal of Policy Modelling, 32, pp. 804-817. 